\title{
The sociology of creativity: PART II: Applications: The socio-cultural contexts and conditions of the production of novelty
}

\author{
Tom R. Burns ${ }^{\mathrm{a}, *}$, Ugo Corte ${ }^{\mathrm{b}}$ and Nora Machado ${ }^{\mathrm{c}}$ \\ ${ }^{a}$ Department of Sociology, University of Uppsala, Sweden/Lisbon University Institute/CIES-ISCTE, Lisbon, Portugal \\ ${ }^{\mathrm{b}}$ Department of Sociology, University of Uppsala, Uppsala, Sweden \\ ${ }^{\mathrm{c}}$ Lisbon University Institute/CIES-ISCTE, Lisbon, Portugal/Sociology, University of Gothenburg, Gothenburg, \\ Sweden
}

\begin{abstract}
This is Part II of a three-part article. The article is predicated on the principle that creativity is a universal activity, essential in an evolutionary perspective, to adaptation and sustainability. This manuscript on the sociology of creativity has three purposes: (1) to develop the argument that key factors in creative activity are socially based and developed; hence, sociology can contribute significantly to understanding and explaining human creativity; (2) to present a systems approach which enables us to link in a systematic and coherent way the disparate social factors and mechanisms that are involved in creative activity and to describe and explain creativity; (3) to illustrate sociological systems theory's (Actor-Systems-Dynamics) conceptualization of multiple interrelated institutional, cultural, and interaction factors and mechanisms and their role in creativity and innovative developments in diverse empirical instances.

The preceding segment of this article, Part I, introduced a general model of innovation and creative development stressing the socio-cultural and political embeddedness of agents, either as individuals or groups, in their creative activities and innovative productions.

This second part, Part II, investigates the "context of innovation and discovery" considering applications and illustrations ranging from, for instance: (i) "the independent innovator or entrepreneur" who exercises creativity based on absorbing a field of knowledge, concepts, challenges, problems, solution strategies, creativity production functions or programs (and who is likely to be in contact with libraries, relevant journals and may be directly or indirectly in contact with a network of others); (ii) groups in their particular fields operating greenhouse types of organization driving problem-solving and creative activities - both self-organizing groups as well as groups established by external powers (whether a private company, a government, or a non-government organization or movement); (iii) entire societies undergoing transformations and radical development as in the industrial and later revolutions. Part III of this article investigates and analyzes "the context of receptivity, selection, and institutionalization" of novelty.
\end{abstract}

Keywords: Creativity, innovative development, system theories, sociology, psychology, field, agency, rule regime, creative production function, phases, context of creativity, social organization

\section{Introduction}

This is Part II of a three-part article. The article is predicated on the principle that creativity is a universal activity, essential in an evolutionary perspective, to adaptation and sustainability. This manuscript on

${ }^{*}$ Corresponding author: Tom R. Burns, Department of Sociology, University of Uppsala, Sweden/Lisbon University Institute/CIESISCTE, Lisbon, Portugal. Tel.: +46 070 8247050; E-mail: tomnora. burns@gmail.com. the sociology of creativity has three purposes: (1) to develop the argument that key factors in creative activity are socially based and developed; hence, sociology can contribute significantly to understanding and explaining human creativity; (2) to present a systems approach which enables us to link in a systematic and coherent way the disparate social factors and mechanisms that are involved in creative activity and to describe and explain creativity; (3) to illustrate a sociological systems theory's (Actor-SystemsDynamics, ASD) conceptualization of multiple

ISSN 0167-2533/15/\$35.50 @ 2015 - IOS Press and the authors. All rights reserved

This article is published online with Open Access and distributed under the terms of the Creative Commons Attribution Non-Commercial License. 
interrelated institutional, cultural, and interaction factors and mechanisms and their role in creativity in diverse empirical instances. ${ }^{1}$

The preceding segment of this article, Part I, introduced and applied a general model of innovation and creative development stressing the socio-cultural, institutional, and political embeddedness of agents [13,30], either as individuals or groups, in their creative activities and innovative productions. The model introduces and applies key concepts such as rules and rule regimes - norms, roles, institutions, and cultural formations that is, in general, social structure. Moreover, it identifies socially based creativity production functions and particular cognitive and action mechanisms as features of rule regimes that generate innovations. In Part I, the general model differentiated analytically between processes of creativity, on the one hand, and processes of institutional acceptance and realization, on the other hand. The phase structure model introduced in Part I distinguishes and specifies the complex of phases of origination and innovation generally - "the context of innovation and discovery" - and the complex of phases of acceptance and institutionalization - "the context of selection, legitimation, and institutionalization." Part II here deals with the context of and conditions of innovation, while Part III will examine the context and processes of acceptance, legitimation and, institutionalization of innovation.

The sociological systems model outlined in the article helps us to address and answer such questions as:

(1) Who are the agents likely to initiate innovation and creative developments - in particular, what are their social positions, if any? What drives an agent or group of agents to initiate creative action?

(2) Agents and mechanisms are identified that not only initiate and facilitate but alternatively, constrain or block creative processes and the institutionalization of an innovation. Also of concern is the reversal of "successful" innovations or the severe restriction of their applications.

(3) What is the nature of an innovation or creative action: ideas, artifacts, products, institutions, cultural formations, socio-technical systems, in general, "system" complexes.

(4) Through what mechanisms - how - and with what "ingredients" is creativity or innovative

\footnotetext{
${ }^{1}$ Burns (2006) provides an overview of several sociological systems theories.
}

action accomplished? Our approach identifies diverse creative strategies and production modalities activated and applied by an innovative agent(s).

(5) What social conditions/contexts are conducive to agents initiating creative action and facilitating creativity activity and the production of novelty and innovative development? And what are major constraining and blocking factors and mechanisms relating to an innovative initiative or creative development?

This second article, Part II, investigates the "context of innovation and discovery" considering applications and illustrations ranging from, for instance: (i) the independent innovator or entrepreneur who exercises creativity based on absorbing a field of knowledge, concepts, challenges, problems, solution strategies, creativity production functions or programs (and who is likely to be in contact with libraries, relevant journals and may be directly or indirectly in contact with a network of others); (ii) groups in their particular fields operating greenhouse driving problem-solving and creative activities; included here are self-organizing groups as well as groups established by external powers (whether a private company, a government, or a non-government organization or movement); (iii) entire communities and societies initiating transformations and radical developments as in the early industrial revolution and the currently ongoing "sustainability revolution" (discussed later).

This article, Part II, distinguishes a number of different social organizational contexts of creativity, which opens the way to apply group [22, 29] and social organizational theories [14, 21, 57] as well as social network theories $[25,48]$ to the description and analysis of creativity in diverse organizational contexts. The approach also distinguishes primary creative processes (initial origination or formation of a novel or creative development) from secondary creativity (for instance, innovations associated with applications and institutionalization) (Parts II and III, respectively).

\section{Diverse contexts of innovation: Brief overview with illustrations}

\subsection{Introduction}

(1) Creative activities reflect their inputs such as the agent(s) involved (her/its knowledge, 
capabilities, and self-confidence as well as her/its particular motivations), the resources (technologies and materials), and the diverse organizational arrangements and processes in which the agent(s) is embedded and which regulates and channels creative initiatives. These processes entail social definitions and constructions - in a particular social field or arena: whether in defining problems, possibilities for solutions, opportunities for innovating and mobilizing symbols, methods, resources in the creative as well as the application phases of innovation.

(2) Agents' creative actions and interactions entail taking available elements (symbols, rules, materials, constructions, resources and creating, transforming, recombining) and producing something new (see Figs. 1 and 2 in Part I, and $3 \mathrm{~A}$ in this Part II).

(3) Individuals and groups may operate under norms encouraging innovation, and creative action generally and norms allowing for divergent thinking, toleration of deviance (at least in some areas). ${ }^{2}$ Or agents are involved in a task-oriented, problem-solving climate which drives them to experiment, test, and innovate. In a certain sense, a creative ethos has a normative base.

(4) In an encompassing socio-cultural climate some agents may have definitive, fixed ideas about what are potential innovations as opposed to "obvious" dead-ends. This might contrast with actors characterized by flexibility in their ideas and practices and readiness to experiment or readiness to try almost anything. Both orientations have their risks of failure to innovate or to innovate in effective ways.

(5) There are institutionalized systems (group forms) for discovery or invention (see, for example, discussion below of Xerox) - such systems play a major role in the modern world: research institutes, R\&D centers, consultancy groups, think-tanks along with a variety of methods such as data and text mining, induction

\footnotetext{
${ }^{2}$ The ethos of democratic culture (that is, not simply ballot box and elections) has been historically a key to many creative developments (and the agents driving them). Such a culture consists of norms, not only of equality but of mutual respect, fair play, tolerance for some degree of deviation, and allowing openings and opportunities for creative initiatives. (However, as we stress in Part III, powerful norms (for instance, of religion or politics), institutional arrangements, and agents may countervail, or block innovations and creative developments).
}

from experience, use of discovery media, etc. (6) Also important in understanding creativity is that individuals and groups may move back and forth across disciplinary or knowledge boundaries - that is, inter- or trans-disciplinarity - putting them in a better position to combine new elements in original ways and more likely to realize an innovation. ${ }^{3}$

\subsection{Illustrations of creative processes and actions in diverse social organizational contexts}

Illustrations of innovative processes and creative developments are found in our earlier studies of power, social change, entrepreneurship and technological development $[6,18,20,55]$. For instance, a series of studies of municipal entrepreneurship and transformative initiatives at energy savings and innovations toward sustainability were conducted by one of us collaborating with several research associates during the period 1980-1985 in Europe and North America (Gothenburg and Uppsala, Sweden; Nysted, Denmark; Metz, France, Saarbrücken, Germany, and Davis, California) [55]. (Municipalities are agents somewhat like the state consisting of complex institutional arrangements, networks, and alliances of diverse agents with responsibility for and authority over defined populations of agents in a given territory). The studies entailed investigating cognitive shifts and reframing, power mobilization and institutional innovation to conserve energy, to substitute for oil with renewable energy sources, and to improve energy planning and regulation, for instance, in the formulation of new building codes and in physical planning. The municipal studies showed that creative potential and entrepreneurship were highly diffused. Innovative initiatives toward greater sustainability could be launched by very diverse actors and emerge from diverse institutional spheres and positions: politicians, bureaucrats, utilities, grassroots engaged citizens, consultants (it needs to be emphasized that sustainability was not part and parcel of the language and discourses of the times). Either on the basis of their own positions of power and/or mobilizing support from other power agents, the initiating agents created designs and programs and brought about a series of innovations toward sustainable development. That is, not only did the initiators formulate new ideas and

\footnotetext{
${ }^{3}$ Arthur [4] points out that Copernicus and Mendel were priests, Galileo and Galvani were physicians. The concepts of brokerage and technology brokering are relevant here $[31,32]$.
} 
designs but they mobilized resources - or convinced others key agents to make it possible - and exercised power and meta-power to bring about transformations toward more sustainable energy systems $[6,55]$. Many promising programs were blocked, however, because of a discrepancy between will and wherewithal (see later). In general, changes in regimes, in production and supply systems, and in the means for determining and implementing policy and programs require actors with the will, knowledge, and power resources to bring about significant change. In the successful initiatives, the change agents had mobilized sufficient power resources and operational knowledge to realize their creative designs and to bring about successful transformations.

The motives for action among entrepreneurial agents in the municipalities were as varied as their settings [55]. Often a different rhetoric for energy conservation framed the same solutions. For instance, in Metz, France, a conservative mayor promoted energy conservation as a way of coming to terms with an inflated municipal budget, while in Saarbrucken, Germany, an ambitious socialist mayor challenged by Green environ-mentalists sold energy conservation as "alternative" environmentalism. The German and French cases also revealed how key political actors utilized the energy issue as a way of becoming more widely known, for instance nationally; innovation could be a ticket to national fame. In Nysted, Denmark, and Davis, California, local citizens became "politicians" and "shakers and movers" because of their concern about the energy issue. In Gothenburg and Uppsala, Sweden, the distance of energy issues from the action of Swedish municipal politicians reflected a general perspective that defined energy as primarily "a technical, de-politicized question." This was, in part, a result of the drawn-out and politically volatile nuclear debate in Sweden in the 1970s. Engineers and other technicians at the municipal utilities stepped up to play the role in taking initiatives to develop alternative energy sources. These illustrations and discussions in Part I suggest the great diversity of settings for creative processes and acts, even in the case of similar fields of concern.

The most obvious sociological instances of creative action concern groups, networks, large-scale organizations, and communities. But even individual innovators operate in a sociocultural context, for instance, the particular "field" setting [43] in which they act that plays a significant role in the problems they identify and the methods and conceptions, algorithms, and heuristics they find to bring to bear on any given problem or challenge. $^{4}$

Below we discuss briefly for illustrative purposes creativity in diverse social and organizational contexts.

\section{Independent innovator or entrepreneur \\ ("Free-lancers")}

Individuals in their socio-cultural contexts are typically embedded in a rich legacy with links to ideas, problems, possible solutions, and possibly key resources (including free or leisure time to devote to creative work).

An individual may have access to a field's cultural and technical legacy. ${ }^{5}$ For instance, individuals in mathematics, literature, music, art, theoretical scientists where the concepts, symbols, and materials are ready at hand, as in the cases of the conceptual and mathematical creations of quantum physics or modern economics and many other fields. Increasingly, some work in contemporary mathematics and theoretical science also requires access to powerful computers (and even entire batteries of computers).

A particularly far outlier is the case of the Russian Mathematician Grigori Perelman working alone on revolutionary creations and living as a recluse with his mother in St. Petersburg, although he has been associated with several major institutions in Russia and the USA. ${ }^{6} \mathrm{He}$ is recognized for providing proof of the Poincare conjecture in 2002, one of the most important accomplishments of 20th and 21st Century mathematics. Perelman's work did not appear "out of the blue." Poincaire's conjecture had existed as a mathematical challenge since 1904. There had been a number of attempts to prove it, all failed. Richard Hamilton provided a partial proof (1982) which Perelman was able

${ }^{4}$ Parker and Corte conceptualize "a field" in such terms (Parker, J. N. and U. Corte 2014 "Collaborative Creativity: Toward a Comprehensive Theory of Creativity from Groups to Fields." Ms.).

${ }^{5}$ Most innovators do not simply passively absorb essential knowledge but engage in self-education, and travel to learn new concepts and techniques, or to obtain examples from distant places (Western painters obtained Japanese water prints and relevant techniques, patterns, and themes; similarly, the influence of African Art on Western materials, techniques, and themes). Or artists very accomplished with oil painting or watercolors visit workshops to learn engraving or lithography.

${ }^{6}$ Many modern artists require access to special materials which they apply or use in their artistic productions. The infrastructure essential to artistic production has been emphasized by Howard S. Becker [7]. 
to extend to create a satisfactory solution. ${ }^{7}$ Three teams of mathematicians took on the task to verify the proof given by Perelman (verified in 2006). He was awarded the Field Medal in 2006 (considered by many as the equivalent of the "Nobel Prize" in Mathematics), and in 2010 he also received the Clay Millennium Prize of a million dollars, and the European Mathematical Society Prize, but refused to take any of them.

Numerous artists and other innovators - many working entirely on their own - require however their materials and technologies, access to particular infrastructures in the field, for instance, in the case of artists, opportunities to exhibit in galleries and museums [7]. These are the infrastructures of the innovators' productions and performances. In addition, they draw on educational opportunities, the teaching of techniques and skills which are part and parcel of any established field. The mathematicians, Benoit Mandelbrot, the creator of fractals, required access to computers to produce the complex patterns of many of his fractals. He was able to exploit the powerful computers available at IBM where he was employed in the creation and development of fractals; he had a long career working to a great extent on his own.

In general, there is a social, cultural, institutional infrastructure - a social context for creativity - not simply a psychological state of mind, although individuals engage in psychological processes making use of socially derived elements. At a minimum, individuals who are creative are embedded in a cultural and social field which provides the symbolic elements, angles of approach, strategies, partial solutions, established procedures and principles [23]. Also, essential to their creative efforts may be access to special technologies such as laboratories, experimental equipment, and powerful computers, opportunities to communicate their ideas and exhibit/demonstrate their creations, and obtain feedback for corrections and ultimately acceptance. The key is that the capable, self-confident

\footnotetext{
${ }^{7}$ Imitation and adaptation on the basis of a new or different purpose or application are characteristic of creative strategies in networks. Beethoven copied the work of other musicians which was readily available to him and adapted it according to his own ideas and passions. For instance, when he decided to compose a quartet for the first time, he copied an entire Haydn quartet in order to learn and use it as a form in launching his own work; similarly, in his final piano sonata, he made use of passages from Haydn and Mozart. Shakespeare (1564-1616) and others at the time copied from one another without much ado. These were the rules of the game at the time in contrast to those of the contemporary ethos of copyrighting as much as possible.
}

agent(s) are in touch with the major issues, questions, and also possible solutions or pieces of solution that are circulating in relevant networks of the field $\mathrm{F}^{8}$

\section{Networks (professional and occupational)}

In many instances, innovators are involved in networks (and quasi-groups). Typically, these may provide access to information, knowledge, critique, potential social support and connections, for example, to professional associations as well as access to essential materials, technologies, and sources of financing and other resources. $^{9}$

Consider the following illustrations.

A. The Norwegian Nils Henrik Abel (1802-1829), one of Europe's greatest mathematicians, had a short career but benefitted greatly from involvement in European networks of mathematicians. His mathematical talents were recognized early and led to educational and funding support from teachers and others in Norway. He was able to make use of all the latest mathematical literature in the University Library in Oslo (the University of Christiana at that time), a period of mathematical flourishing in Europe. After graduation and with support from his professors and a state fellowship, he travelled widely in Europe (Berlin, Leipzig, Basel, Prague, Vienna, Paris, among others cities) meeting mathematicians and editors of mathematical journals and presenting his early mathematical concepts, categories, theorems including his highly original work on group theory, abelian groups, and abelian functions, an extraordinary cascade of mathematical creativity, all generated before he died of tuberculosis in 1829 (27 years old) and much of it well-received. ${ }^{10}$

\footnotetext{
${ }^{8}$ Typically, this access is unevenly distributed across a field making some individuals both better positioned to create, and also be recognized for their efforts. Collins [25], among others, refers to this asymmetry. Collins [26:436] argues that one of the reasons why Freud received more recognition than the efforts of his collaborators -Josef Breuer and Wilhelm Fliess - partially Lays in the fact that Freud has a much stronger, and central network than the other two.

${ }^{9}$ Drawing on a social variant of autopoiesis systems theory [56] (which shares commonalities with Niklas Luhmann's socioloical theory), Zeleny [57] analyzes entrepreneurial networks of small and medium size enterprises as organic systems (with a number of specified rules, a rule regime) that assures that the networks reproduce themselves (self-sustaining) and maintain their coherence.

${ }^{10}$ Ironically, he saved what he considered to be one of his most important papers, which he submitted to the French Academy of Sciences but the reviewer, the well-known mathematician AugustinLouis Cauchy, forgot about it, and it did not appear until after Abel's death. His work drew upon and developed (sometimes in parallel
} 
The functioning of scientific networks is also illustrated in the case of Albert Einstein (1879-1955), among thousands of other creative scientists. ${ }^{11}$

Although he worked to a great extent on his own, he was not a recluse (compared to the mathematician Grigori Perelman discussed above), but participated in physics conferences and maintained exchanges with colleagues in Physics as well as collaborated with a number of others in his European network (Leopold Infeld, Nathan Rosen, Leo Sziliard, Boris Podolsky, among others). Some of his best early work was submitted to the Annalen der Physik, one of the most recognized physics journals. In 1905, while working in a patent office he published his dissertation in Annalen along with papers on the "photoelectric effect," "special relativity," "the equivalence of mass and energy $(E=\mathrm{mc} 2)$," and "Brownian motion," all cutting edge contributions (Einstein won the Nobel Prize in Physics in 1921 for the work on the photoelectric effect). This research was at first ignored but by 1908 began to be acknowledged, and Einstein received academic appointments and lectured widely in Europe and the US. He had drawn conceptually and professionally from and contributed significantly to the highly developed, rich fields of physics established in Europe at the end of the 1800s and early 1900s. Interestingly, he made major contributions to quantum physics but rejected the basic conception claiming over many decades that it was incomplete, and that a more complete theory would eventually emerge to replace it. He also worked until his last days to develop a theory unifying the fundamental forces of nature. In spite of these deviant but highly creative paths he choose in the latter part of his career - which isolated him from many of his colleagues - he had more than proved himself with his revolutionary ideas in the first half of the 20th century. ${ }^{12}$

\section{Small organically formed groups}

Many creative actions involve (even require) partners (of varying qualities and capabilities) such as in the collaboration between composers and lyricists, or in science, a physicist and mathematician (as in Albert

with) the great advances in concepts, methods, systems of mathematics in $1800 \mathrm{~s}$.

${ }^{11}$ Ludwig Wittgenstein (1889-1951) was a contemporary of Einstein who worked more or less on his own in philosophy, but was embedded in key national and international academic networks.

${ }^{12}$ Another revolutionary scientist, Alfred Russell Wallace, worked much on his own in developing his approach to evolutionary theory (although he exchanged letters with leading scientists of the time including Darwin).
Einstein's work with the mathematician Marcel Grossman on the general theory of relativity), or Crick \& Watson in conceptualizing DNA; or Farrell's diverse creative groups [29] science groups [46], and Corte's creative sports group [22].

- Collective creative actions. Participating actors contribute different types of knowledge, information, skills - or problem-solving capabilities to address multiple puzzles or uncertainties. ${ }^{13}$ In addition, they may effectively function to motivate individuals involved in such groups in spite of a number of hindrances they are likely to face [29].

In music, for example, composers, collaborate with songwriters (as in the case of Richard Rogers (1902-1979) and Oscar Hammerstein (1895-1960), George Gershwin (1898-1937) and Buddy DeSylva (1895-1950); but the composer may also take a given text and write the music for it, as Beethoven did for his ninth symphony without any direct collaboration.

\section{A. Freestyle BMX (bicycle MotoCross) circle}

Corte [22] describes a BMX circle that emerged in Greenville, North Carolina beginning in 1995. It consisted of professional riders of circles from various distant towns and cities who migrated to Greenville because they found there a dense network of people who shared their identities and interests in a setting which was conducive to their goals. By congregating in Greenville and attracting one another (some were already friends or acquainted with one another from competitions), members maximized homogeneity in cultural backgrounds, stages of career, and ages of the members all of which facilitated collaboration. Crucial to their creative initiatives was an available skate-park and moral support from the local community that afforded the group the space and time it needed to unite, articulate a common vision, and produce dramatic innovations in their sport that advanced it technically, aesthetically, and professionally.

\footnotetext{
${ }^{13}$ Arthur [4:164] stresses general problem-solving: “...innovation emerges when people are faced by problems (questions). It arises as solutions to these are conceived by people steeped in many means many functionalities - they can combine. It is enhanced by funding (resource availability and mobilization) that enables this, by training and experience in myriad functionalities, by the existence of special projects and labs (groups, networks) devoted to the study of particular problems, and by local culture that fosters deep craft. But it is not a monopoly of a single region, or country, or people (or even culture). It arises anywhere problems are studied (identified) and sufficient background exists in the pieces that will form solutions (creative, innovative)."
} 
These riders were motivated by similar professional goals, possessed similar capabilities, and were familiar with each other from having met at various competitions over the years. Collectively, their accomplishments attracted national attention. In March 2001, Ride BMX Magazine, a niche publication dedicated to BMX riding, dubbed Greenville "Pro Town USA." Inspired by the success of the Greenville pros, a large number of professional and amateur BMXers began relocating to Greenville in the early 2000s. Many riders who did not move permanently still visited for extended periods of time (often more than once and sometimes regularly), as it became an important destination in the field of BMX for the goal of pushing the limits of their activity. Corte maps the way in which a core membership of "pros" was built up and functioned [22]. Together, the core became a collaborative circle [29]. The group developed a common rule regime, leadership, and a resource base, in particular, values and norms concerning performances, competition, and group behavior, the idea of technical progression, professionalism, the importance of participating in major competitions, and norms of access to and use of the ramp park. The key factors related to the resource base of the group revolved around the free access of the group to the first, public, ramp park (which was quite singular of this specific location on a number of respects), the possibility of riding in private-with an almost total exclusion of outsiders, and the opportunity of riders to live very close to one another and participate in many spontaneous interactions which also contributed to forging their friendships.

\section{B. Crick \& Watson and the discovery of DNA's structure}

A much publicized collaboration involved Frank Crick and James D. Watson in the "discovery" or formulation of the DNA model. ${ }^{14}$ Not only did they discover one another, but they were linked to a number of collaborative and competitive groups, which they were able to draw upon and exploit in the development of their revolutionary model (in particular, key researchers in the area such as Linus Pauling, Jerry Donohue, Erwin

\footnotetext{
${ }^{14}$ Pairs are one of the most common and fruitful "network ties:" husband-wife teams, brother and/or sister teams, etc. but also mentorprotégé ties whether in the areas of art, science, management, or politics (e.g. Steiner [37]). As argued here, novelties emerge out of interactions as problems are jointly identified and collaboratives initiatives are devised and taken to solve them.
}

Chargaff, Maurice Wilkins, and Rosalind Franklin). ${ }^{15}$ While Crick and Watson used more conventional methods of investigating DNA, Maurice Wilkins and Rosalin Franklin utilized advanced X-ray diffraction methods to investigate and understand the physical structure of the DNA molecule.

It was a complex structure: the molecule was a double helix. It was also important to figure out that the two strands run in opposite directions and that the molecule had a specific base pairing. Others were engaged in resolving some of these issues - a number of scientific breakthroughs occurred that prepared the backdrop/context of the ultimate DNA formulation: the technical progress and development of skills achieved by X-ray crystallographers in studying organic macromolecules; the growing evidence supplied by geneticists that DNA was not a simple protein, and that the chromosomes were responsible for heredity; Linus Pauling's discovery that the molecules of some proteins have helical shapes-he arrived at this through the use of atomic modeling. While Pauling made the mistake of formulating a triple helix shape, which Crick and Watson had already judged as unsuitable, the ultimate key to solving the puzzle in this highly competitive field was that they gained access to Rosalind Franklins Xray photographs without her permission. In particular, "photo-51" revealed a helical structure - double helix, not triple!; She hesitated in presenting her results, while Crick and Watson rushed to publish their famous article in Nature, April 25, 1953. Ultimately, they received the Nobel Prize with Maurice Wilkins, leaving Rosalin Franklin out. ${ }^{16}$ Clearly, the large networks of researchers extended over time and space provide a better understanding of the processes in back of the "discovery" of DNA than the notion that two "geniuses" Crick and Watson managed this discovery on their own (not to detract from their important contributions).

The conceptualization of DNA entailing a long history and hundreds (probably thousands) of researchers is a great scientific accomplishment. Almost all organisms - bacteria, plants, yeast and animals - carry genetic information encapsulated as DNA. The DNA concept and the array of tools and methods mobilized to

\footnotetext{
${ }^{15}$ But the intellectual legacy goes much further back, for instance to 1869 when the Swiss chemist Friedrich Miescher isolated and identified DNA. Over many decades research was conducted to identify the function of DNA (eventually seen as the "molecule of life") and its composition and structure.

${ }^{16}$ Only three recipients are permitted, but subsequent investigations revealed that no one ever nominated her - neither for the Nobel Prize in Physiology or Medicine nor for the one in Chemistry).
} 
investigate it, continue to play a powerful driving force in the diffusion and cascading of innovations and creative developments (see Part I on cascading) through networks of users and potential users of the ideas, methods, etc. and including scientific associations, conferences, and journals.

Large numbers of groups behave in the creative ways described above not only in the process of formation with the mobilization of people and resources and the construction or adoption of a rule regime - but in their functioning and development (or possible demise).

\section{Constructed or "legislated" groups and organizations aimed at creative undertakings}

Such initiatives are taken in the context of, for instance, large companies, government agencies, and universities. Many innovative efforts require many collaborators (specialists and experts of different types) and substantial resources which are very difficult to mobilize organically ("spontaneously") but rather require the initiative and investment on the part of largescale or wealthy organizations:

A. The Manhattan project (1939-47) was established by the U.S. government to produce the first nuclear weapon - leading to the massive destruction from the atom bombs dropped on Hiroshima and Nagasaki. Other major highly organized initiatives are exemplified by Disney cartoons and film productions, PARC (at Xerox) to develop an early PC (all discussed by Bennis and Biederman [8]) who emphasize the strong commitment in these systems to task-oriented norms, intense involvement, and readiness to trespass boundaries and also accept critique (see below). Resources for the Manhattan project come from the U.S. Government, for the Disney system from within/outside Disney, and in the case of PARC from inside Xerox for the development of an early PC. ${ }^{17}$

In such large, complex systems as the Manhattan Project, there are multi-interrelated roles: the director was not a scientist, but a U.S. Army officer, General Ledslie Groves of the U.S. Army. He played a key role in protecting the project, helping to obtain the resources necessary, supporting recruitment of some of the best people available, resolving misunderstandings and conflicts, managing the large community of odd balls and

\footnotetext{
${ }^{17}$ There are many other examples of highly creative groups and organizations established for purposes of performing innovatively: Bell Labs, Cavendish Labs, Stanford Computer Science Center, Stanford Linear Accelerator Center (SLAC), and Europe's CERN, among others. Concerning highly creative complex organizations see Hollingsworth et al. [33] and for organizing creativity see Chen [21].
}

intellectual divas who participated in the project. The project grew to employing 130,000 at 30 sites across the U.S., Canada, and the U.K. (It cost 26 billion (in 2015 collars)). ${ }^{18}$

B. Palo Alto Research Center (PARC) and the Development of the First Personal Computer [8]. ${ }^{19}$ PARC, a research and development adjunct (from 1970) of the Xerox Corporation, was established with about 50 persons to create a personal computer. From their networks, two key people at Xeros (Alan Kay and Bob Taylor) recruited in a meticulous way people with demonstrated intelligence and creativity - but the recruiters also believed that collaborative skills were especially important for the type of systems-oriented research such as PARC would be undertaking.

The group was designed to be non-hierarchical at the same time that the management of the group developed and applied a strategy to deal with conflict among members and predispositions to become prima donnas. Norms were "legislated" by the leadership, insisting on sharing information, and on a regular basis; open weekly meetings were mandated for the group. At the same time, people participating in PARC experienced a great deal of emotional excitement (collective effervescence [27]), and became highly devoted to the group and to the task, sensing that they were involved in a major cause for humanity.

Management worked to assure that the group had the right tools for their work - and allowed them to create these for themselves if they were not available elsewhere. It managed on a sustained basis to persuade the top management decision-makers of the urgency of the PARC group initiative and its performance needs and to obtain financing and other resources for the group.

The group succeeded with its challenging task, creating the first PC, the "Alto," which had many of the features that are standard to PC and MAC users: bit mapping, a graphical user interface (and Ethernet),

\footnotetext{
${ }^{18}$ Film-making also entails multi-interrelated roles: the role of "resource mobilizer" is often not the same as the role of the creator(s) - the former is the "producer" mobilizing the financing for a film project as distinct from the film director or writer of the script; camerapersons as well as actors and actresses are not only interpreting but often contributing to the script and its representation - an entire shortlived community, whose members are motivated by money, challenge and adventure, companionship, possibilities of recognition and fame, and whatever else might be associated with the enterprise.

${ }^{19}$ The story has a long time span. Bennis and Biederman [8] refer to the "archeology of the idea" of the computer, the many decades from an early vision to concrete substantive innovative results, multiple creations and transformations; cascades of ideas and innovations that resulted in and followed the first PC computer.
} 
pop-up menus, and the mouse. In addition, the group developed the first easy-to-learn word processing program, and the first laser printer. As it turned out, XEROX decided not to develop the Alto PC commercially, and variants of it came to be developed by Apple and other companies including IBM.

Formally organizing or constructing groups - even those engaged in creative activities - is an established part of the contemporary world. From uncertain beginnings such as Thomas Edison's Menlo Park laboratory, such organizing of creativity groups has been applied in almost every field of human endeavor. ${ }^{20}$

Large numbers of groups behave in the creative ways described above not only in their initiating phase - with the mobilization of people and resources and the construction or adoption of a rule regime - but in their functioning and further development.

\footnotetext{
${ }^{20}$ Civil society institutions and networks are populating the world with associations, some of them with substantial mobilized powers and creativity such as WWF and Physicians without Borders. One "legislated" group in the area of palm oil production entailed not only innovation in the collective governance of the group but as a producer of innovations. In the late 1990s, the WWF developed its "Strategic Action on Palm Oil and Soy" because it concluded that the expanded production of these two crops were responsible for the rapid conversion of the world's major virgin tropical rain forests and dry savannah forests into croplands [44]. For the WWF, there were connections between everyday consumer products (such as margarine and fats, found in thousands of products) and the destruction of the rainforest through the expansion of palm oil plantations. In 2002, the WWF mobilized industry actors (palm oil processing and trade companies, financial players, and retailers and food manufacturers, among them Unilever, Body Shop, and major plantation owners, environmental NGOs, among others) to negotiate the formation of the "Roundtable on Sustainable Palm Oil" (RSPO). During two years of discussion, investigations, and negotiations, RSPO was designed and eventually established formally in 2004 as a non-profit Swiss association. Members provided resources such as, of course, funding, expertise, meeting venues, etc. Unilever provided a CEO to lead RSPO. A RSPO rule regime was articulated and adopted and legitimized by the membership. It concerned membership, governance arrangements, regulatory programs, standards of certification, and more. In particular, a rule complex for certifying "sustainable palm oil" was agreed upon, to ensure that palm oil plantation expansion and production would not be based on destruction of Malaysian or other rain forests. This purely private association and its governance system - established in the face of solid evidence of a lack of reliable government policy - is still functioning but with a number of limitations as well as some potentialities for further development [44]. There are a number of parallel developments. For instance, another association, The Forest Stewardship Council (FSC), is one of the most recognized cases of a major NGO constructed by multiple private actors in order to establish and enforce new rules to protect forest commons. FSC was constructed through multi-agent deliberations and decision-making as in the case of RSPO. McLaughlin [46] points to associations as significant objects of research in terms of "collaborative circles."
}

Macro-societal initiatives: The modernizing state as a creative force.

A. Early Swedish Development of Public Health (1700-1800s): Structural Innovation and the Successful Regulation of Death through Social Organization [41]. This progressive development was particularly noteworthy in the 1800 s, which saw an "epidemiological revolution" in the area of public health [41]. The driver was the central state which mobilized a small group of medical professionals (there were very few physicians in Sweden in this period of very substantial poverty) together with mid-wives and the Lutheran priesthood (which was closely associated with the Swedish state). The 'rustic' style of sickness and dying in the Swedish town and villages was changed by the mid-1800s as a result of systematic state intervention.

The Swedish state early on (1500s) took responsibility for dealing with sickness and death and improving the health of the entire population. In the course of two hundred years, it developed a new and unique social organization, the elements of which were later to be characteristic of "The Swedish Model" of governance [17]. Although roots go back much earlier, the state developed during the 18th and 19th centuries a multi-level governance system which facilitated communication and negotiation between the center and local society and also engaged key stakeholders such as priests and midwives in issues of health, illness, and death.

At the top of the governance system was the Crown and a group of medical professionals organized in the Collegium Medicum (a Royal Expert Panel of advisors, earlier the Collegium Medicum). In 1813 the latter was transformed into the Health Collegium, a formal state agency). Locally there were 2000 parishes (socken) (with their priests and local organizations such as parish assemblies (sockenstämman)), ${ }^{21}$ midwives (eventually

\footnotetext{
${ }^{21}$ In the Reformation the Swedish state acquired power over the church and incorporated its property and wealth under its administration. The 2000 parishes (and towns) with priests, in addition to their religious and educational pursuits, were to deal with worldly tasks such as in this case, public health, under State leadership. The churches disciplinary activity (kyrkotukten) contributed, it can be argued, to the fact that Swedes became a particularly easily disciplined and obedient people in relation to the state - who without reflecting or protesting found themselves to be commanded by authorities/the powers that be (overheten). Swedish authorities strove to maintain peace and order and to limit unrest and conflict. This social disciplination and control, however, was not necessarily against local elites and majorities but engaged them in an early form of corporatist arrangement for communicating and negotiating policies and programs (see footnote 22).
} 
there was at least one in every parish), and initially a number of "district medical officers" appointed by the state. $^{22}$

In general, although there were major resource limitations in Sweden until industrialization in the $1800 \mathrm{~s},{ }^{23}$ a number of highly innovative instruments were established and developed: campaigns for healthy behavior, laws and regulation concerning public health and the regulation of disease and death, vaccination campaigns, protection against contagious diseases, infrastructure improvements, high levels of public participation in improving hygiene and healthy living.

Through these governance arrangements, each and every one of the 2000 Parishes in Sweden could be reached by the decrees, information circulars, ${ }^{24}$ medical handbooks, and supervisory visits. There emerged an organized capability to monitor and deal with everyday praxis concerning water, food, birth and nursing praxis, and a variety of other health conditions. ${ }^{25}$ Also, the governance system had the ability to respond in organized, systematic ways to, for instance, cholera epidemics in the 1800s (there were 9 epidemics between 1834-1873). The District Medical Officers and priests (organizing statistics and participating in treatment and preventive measures) reported to the Health Collegium: letters were sent with accounts and statistics

\footnotetext{
${ }^{22}$ Priests, medical officers, midwives, ands nurses were to a high degree financed and steered by the state and came to see themselves as civil servants (tjansteman) of the state. All of this facilitated the cooperation/collaboration between state and professions - that is, there was a degree of integration between professional perspectives, political decisions, and practical implementation at local levels. Scholars of this period refer to the District Medical Officers and the midwives as the "apostles of Public Health" [41]. The parish clerics should also be included.

${ }^{23}$ There were only a few dozen district health officers in the late 1700 s but this increased to about 500 by the late 1800 s.

${ }^{24}$ Between 1740 and 1850 at least 50 advisory publications on child health alone were brought out.

${ }^{25}$ Reports went to the Health Collegium covering, among other things, sickness and death from smallpox, cholera, typhus, typhoid, scarlet fever, diphtheria and dysentery. Attention was given not only to water supply but water quality and waste water. Also attention was paid to rental apartments and general locales (including factories) - controlling that they were in accordance with hygienic and health. There were controls of latrines, garbage and animal conditions within each Parish and city. Dealing with the dying and the dead - with everimproving forms of classification - also was professionalized and rationalized [1:94-96]. Concerning the latter in the case of France, see Trompette and Lemonnier [54] and Trompette [53] concerning the professionalization and standardization in caring for the dead related to the categorization of death and dead persons and the transformation of the institutional and political foundations of the management of the dead and funeralization.
}

about local developments, health issues, level of health, and birth and death "statistics" (in the form of tables (tabellverket): priests had the responsibility for the yearly Parish-wise reports [41] providing data on births, infant mortality, deaths (distinguished by sex and age); the "death cause" tables were filled in - each row indicating a cause of death, and columns indicating age and gender. $^{26}$

There was a rapid decline in the incidence and mortality of smallpox as a result of organized mass vaccination; infant mortality was also rapidly reduced. There was institutionalized communication about urgent matters (whether quality of water, quality and preparation of food, and issues of sewage, abuse of alcohol, inappropriate or inadequate places of living and types of clothing, failure to nurse infants (rather than start them on local food), insufficient attention to (or response in) situations of sickness and epidemics) Guidelines were prepared for responding to epidemics and the spread of contagious diseases.

In sum, state authorities initiated and developed from the 1700s a valuable channel between the state together with the Collegium Medicum, on the one side, and district medical officers, the clergy, midwives and general public, on the other side. ${ }^{27}$ Death, dying and disease

\footnotetext{
${ }^{26}$ This system entailed not only intervening in a multitude of ways in people's everyday lives, but also advocating education - first, the systematic education of midwives and then priests, and ultimately the population as a whole. "Priest-medicine," a course in basic medical knowledge, was applied in Swedish parishes (the great Carl Linne played a part in this!); priests received and maintained "handbooks in medicine" and had responsibility for parish apothecaries and the "health and illness tables," referred to above. People were being educated about nursing infants, diet, cleanliness, care about water and sewage - the ideology and practice of "hygienism" [41]. Although central influence was substantial, there was a high degree of selfsteering and local legitimacy, since, for instance, the parish assemblies were made up of farmers (who were independent in Sweden), magistrates and burgesses. The assemblies served not only the church's purposes (for instance, literacy campaigns and programs) but also the state's interest in its intentions being accepted and realized. The high legitimacy for collective actions initiated by the state was demonstrated time and time again, for instance, there was relatively low resistance in Sweden (in contrast to more advanced countries such as England and France) to the massive smallpox vaccination campaigns in the early 1800 s but as well a multitude of other interventions in the 1800 s facilitated by the role of priests and local elites as well as midwives and Medical officers (see below).

${ }^{27}$ The Swedish Model of power division, communication, and negotiation often served well not only the state but professions and the general population. The 1900s great reform movements were based on collective exchanges, negotiations, and compromises rested on a long tradition of pragmatism with the result which was neither stamped by a local idyllic community or a system of state oppression [41].
} 
were taken out of the realm of the supernatural, and became medicalized and bureaucratized through professionalization, administration, and central regulation - ironically perhaps for some observers, Swedish priests played a key role in this development. Modern ideological discourses were circulated: "Sickness can be cured," "death can be avoided," "disease can be prevented." And the state along with major professional groups had (and still do have) the responsibility to hinder and prevent death and disease, and to care for and heal the sick.

The Swedish governance arrangements for early public health programs was the cornerstone for the successful policies and the substantial reduction of sickness and morality (including infant mortality) during the 1800s (from average longevity of around 35 years to 55 years by 1900 (and about 80 years now). These accomplishments were in large part the result of the creative and collective meta-powering and transformations carried out by the central government in collaboration with midwives, priests, and local parishes.

B. EU Meta-power Mobilization and Radical Legislation: The Case of EU Chemical Regulation [20]. ${ }^{28}$ REACH (that is, registration, evaluation, authorization, and restriction of chemicals, in effect since June, 2007) was one of the most radical and contentious legislative initiatives of the EU, involving almost 10 years of debate, mobilization, struggle, and negotiations between the Commission, the Council of the European Union, the Parliament, and industry, labor unions, environmental, consumer and animal rights NGOs, among others. ${ }^{29}$ The context for the initiative was the growing international attention and regulatory efforts from the early 1970s (for instance, the UN Stockholm Conference on the Human Environment, 1972). The EU initiative started with an informal meeting in Chester, UK, in March, 1998 engaging several members of the Environmental Council with representatives from Austria, Denmark, Finland, Netherlands and Swe-

\footnotetext{
${ }^{28}$ Central to creativity in modern society are initiatives to reform or transform institutional arrangements (in particular, markets, government, governance arrangements, educational systems, sociocultural and communication systems). These "structuring actions" change intentionally or unintentionally social structures (restructuring or transformation) or maintain social structures (reproduction or morphostasisis) in order to incorporate and institutionalize innovation - or to maintain the status quo. Archer [3] referred to this as structural elaboration Burns et al. [13] and Burns and Dietz [16], drawing on Buckley [9] refer to reproduction (morphostasis) and transformation (morphogenesis).
}

den (Austria, Finland and Sweden had become new EU members in 1995). They determined that something major needed to be done to realize a more effective regulation of chemicals; there were tens of thousands of them whose risks to human health and environment were unknown - or in some cases known but without adequate regulation. The first half of 1998 was the period of the UK's EU Presidency and it selected "chemicals in the environment" as one of the Presidency themes. The Chester group prepared a joint position paper which set in motion new ways of thinking among key environmentally interested agents in the EU about chemical regulation. The initial formulation of a new policy paradigm began to take shape in the legislative bill.

The proposal was designed to cover a major part of all chemicals (substances of either high concern or manufactured or imported over 1000 tones). The legislation would replace about 40 legislative instruments in force at the time. An entirely new European Chemical Agency (ECHA) was to be established (as it was in 2007). Thousands of substances (approximately 30,000 expected) already on the market would have to be assessed and would have to be subject to authorization. New chemicals would have to be tested for safety before being release on the market. The burden of proof of chemical safety was put on the producers, not with consumers or with the regulator as had been the case earlier. Under the new regime chemicals could be banned - or if their value to society was judged to

\footnotetext{
${ }^{29}$ Other EU contentious paradigm innovations are identified and analyzed in Carson et al. [20]. For instance, following the "mad cow disease" scare and other publicly recognized regulatory failures with respect to food in the 1980s and 1990s, EU food governance was redefined in terms of food safety - "healthy food is a public good, not merely a commodity" and food safety policy was moved from DG Industry (later DG Enterprise) to DG Health and Consumer Affairs. A food safety authority, the European Food Safety Authority (EFSA) was created (January, 2002) [20]. The new governance arrangement involved, among other things, re-organization of the Commission. Primary responsibility/authority for handling food policy and regulation was moved from the directorates dealing with agriculture and markets (DG Agriculture and DG Industry) to a new directorate, DG Health and Consumer Protection. The establishment of EFSA indicated a further institutional expression of the new governance paradigm and the institutionalization of its principles and values. Food policy in the EU is no longer seen solely or primarily as a commodity or market issue (as earlier), but also as a health and security matter - this is a major cultural innovation in policymaking and regulation in the EU (as REACH has been). Transformative powers (based on a mandate following the crisis) mobilized new knowledge and let to setting up new power and control mechanisms (a new "design" or paradigm of laws, policies, and institutional arrangements was established for purposes of food regulation).
} 
be very high they could be allowed but under very tight controls - and with a demand that alternatives bediscovered.

There were substantial struggles within EU institutions over supporting or rejecting this highly innovative legislation to regulate chemicals: in Parliament (between, for instance, the Committee on Environment and Committees versus Industry and Legal Affairs); in the Commission (between DG Environment and DG Enterprise), and in the Council itself between the countries (in particular Germany, France, UK) fighting to defend the old paradigm of a privileged position for and limited regulation of the chemical industry and those states pushing for a new, much tougher regime of chemical regulation (in particular, Sweden, Austria, Finland, and Denmark). The US Government and US companies were also key players in these struggles. Arguably, never has a public policy process in the EU involved so many players with such intensity over such an extended period of time. The exercise of multiple powers and the array of struggles characterized Europe's most important industry during the long period 1998-2007 and resulted in major innovations in conceptualizing regulation of chemicals, its institutional arrangements, and array of policies. ${ }^{30}$

\section{Community and society self-transformations ${ }^{31}$}

"Hothouse community contexts" entail creative settings: a special atmosphere, networks, groups and organizations immersed in an atmosphere of

\footnotetext{
${ }^{30} \mathrm{REACH}$ could possibly have been blocked given the formidable opposition. However, (1) EU environmental issues do not require unanimity in the EU (in contrast to EU tax legislation; see Carson et al, [20] about the activation of the rule to block EU carbon and energy tax initiatives); (2) The success of the initiative depended in large part on the fact that the directive (with its intent) was established in the EU legislative process before it could be derailed or blocked by the substantial EU and international opposition. Once established in the legislative process, the main scenario entailed negotiating details between the EU Parliament (supporting the law) and the Council (opposing) with the Commission mediating. That is, the properties of the EU legislative process assured that once a legislative is past a particular point where the legislative intent and general design are set, passage of the legislation is highly likely - only details are negotiable (for instance, between the EU Parliament and the Council representing the Member States) not the legislative proposal itself (unless Parliament and the Council are both opposed to the proposal); (3) the EU President (from Finland) intervened effectively to settle some of the differences and to facilitate the adoption of the radically new governance paradigm, that is, he served to provide an effective procedure of mediation in a contentious process. The case points up the multiple powers (some unknown initially) which make a major innovative initiative and transformation do-able within particular institutional arrangements.
}

problems/challenges, ideas, conceptions, values, and resources - typically attracting people and resources and providing for rapidly cumulative and expanding creative developments (a positive feedback loop). There are many examples [4]: Florence in the 1400s, Vienna during the period 1800-1936 in which networks of Jews played a key role in multiple creative developments (ended by the Nazi takeover of Austria), Silicon Valley, among others. Two cases which we have examined are the early industrial revolution in England and the ongoing, global "sustainability revolution" [10]. These are briefly sketched below.

\section{A. Early Industrial Revolution}

The early Industrial Revolution (toward the end of the eighteenth Century) entailed many small and medium innovative initiatives in the emergence and transformation of technologies, institutional arrangements, social relations, and values such as those relating to the formation of factories, built environments, and entire industries. Such transformations could occur without any single agent or group of agents planning or even negotiating the overall development pattern.

The early industrial revolution involved multiple agents initiating and developing a variety of innovations including new technologies and socio-technical systems. The transformations encompassed not only major innovations in technologies and technical systems, e.g., the great increase in the use of fossil fuel energy (with the industrial use of goal), the invention of the steam engine, the development of mining, textile manufacturing, metal tools, optics, revolutionary advances in transport (with the establishment of railroads and the making of larger and faster ships), among other developments, and, of course, the shift from human/animal power to water and to coal. But crucial to all these engineering and technical advances was the development of innovative organizational and institutional means (including governance arrangements) to utilize and exploit the varying technical possibilities: the rule regimes of factory systems, methods to coordinate and control large numbers of workers, new ownership arrangements, regulatory agencies, legal innovations, the ideas - and realizations of the ideas - of mechanization and of standardized mass production, and new

\footnotetext{
${ }^{31}$ Elsewhere $[15,18]$, we consider a number of creative revolutions: the Meiji Revolution (1868-1945) in Japan, the Shah's Transformation of Iran (1925-1979); Ataturk's transformation of Turkey (1922-2010); the establishment of Communist regimes in Russia (1917) and Eastern Europe (post-World War II) and their ultimate collapse in (1989-90).
} 
research and educational organizations, among other innovative constructions. The revolution encompassed also to a high degree new governance arrangements in diverse sectors combined with machines to make use of, for example coal, iron ore, and cotton - on a scale and with a rapidity never achieved (or imaginable) before. In other words, there were not just machines and material technologies but organizational, legal, conceptual and normative innovations. Almost all aspects of everyday life came to be affected, but with minimum direct or central coordination (although later variants of industrialization (for instance, in the cases of Germany, Japan, and the Soviet Union) entailed more a top-down development guided by an overall design or blueprint). ${ }^{32}$

Inventors, innovators, entrepreneurs, scientists and engineers, business leaders, and government officials took a multitude of creative initiatives not only to make money, but to gain fame and respect, to experience the power of developing and transforming themselves and the world around them, and to advance the national power of in this case Great Britain. Tens of thousands were involved in these developments over the decades during which industrialization emerged and took off. The revolutions in mining, manufacturing, transport, chemicals, and agriculture were followed by those in electricity, electronics, and communications as well as in law, administration, science and education. The development of the industrial social order - with its technologies, experts, and forms of governance and regulatory systems - spread from England to North America and the rest of Europe and eventually to most corners of the globe. ${ }^{33}$

Nevertheless, historically there was substantial opposition to many aspects of industrialization: In a number of countries, for instance, in Europe and North America,

\footnotetext{
${ }^{32}$ Industrialization became a "development" concept which was more than a description. It became as well a metaphor of progress and advancement and a powerful normative idea (to be "developed", "industrialized" was good, to be undeveloped or underdeveloped was backward, a failure (see [40]).

${ }^{33}$ As a significant part of the development, the environment was exploited to the fullest for economic and related purposes; "unspoiled areas" were defined as "wasted" and "should be effectively exploited" in the name of progress and "welfare." The great success of the industrialization paradigm reinforced the idea that humans could ignore or, at least, overcome, environmental detriments and resource problems. Consequently and progressively, industrial society engaged in a reckless and extensive exploitation of nature. This was done on the basis of faulty assumptions and conceptions of real impacts and in many instances, in ignorance of long-term environmental and social consequences, as we have been learning since.
}

concerns about urbanization, pollution, water and air quality, and deforestation, and resource depletion generally led to powerful opposition movements. NGOs were founded to promote environmental protection, conservation and wildlife protection-a whole battery of policies, programs, and parks were established as a result. For workers, socialist and trade union movements emerged to fight for social protection, welfare, and justice. These movements and the governance and regulatory developments that they helped bring about operated on many levels and with varying degrees of effectiveness in the course of industrialization.

B. Emergence of a potential sustainability revolution. Today we may be witnessing the early stages of a new societal revolution comparable in scale and import to the industrial revolution $[5,10,11,28]$. This "sustainability revolution" - sustainalization - implies a new type of society - or family of societies. It is being forged, piece by piece "organically," so to speak. Innumerable "sustainability" designs, plans, and initiatives at different levels have been developed as people try to forge new orders (local, meso-, and macro-) as occurred in the case of industrialization. Another way of thinking about this transformation is that a "green" or sustainalization world is emerging - just as an industrial world perspective emerged in and through the industrializing process. Already, there are emerging new concepts, scientific efforts, policy schemes, a new language, an organic transformation of our ways of thinking, judging, and acting, etc. [10]. A societal paradigm shift appears to be taking place.

From the 1960s there has been rapidly increasing global awareness and concern about damage to the environment - Rachel Carson's book (The Silent Spring, [19]), the UN Stockholm Conference on the Human Environment (1972), the 1987 Brundtland report (The World Commission on Environment and Development, Our Common Future), the 1992 Rio de Janeiro "Earth Summit" (UN Conference on Environment and Development (UNCED)), and so on. The "Stockholm Declaration" was formulated at the 1972 Conference - a number of guiding principles for the protection of the environment was adopted. These have been critical in the successive development of other instruments. $^{34}$

\footnotetext{
${ }^{34}$ Another important outcome of this conference was the agreement to create a new programme. for global environmental protection under the United Nations: Then United Nations Environmental Programme (UNEP).
} 
Increasingly, processes of defining threatening environmental realities, mobilizing agencies, enterprises, and citizens have been taking place. ${ }^{35}$ These processes relate to a cascade of private and public initiatives, movements, and accomplishments in addressing environmental issues and challenges. The UN, environmental agencies, many enterprises, public "intellectuals," researchers, NGOS, environmental movements, and media have succeeded to a greater or lesser extent in convincing themselves and multitudes of others that the environment and human life as well as life generally are threatened on planet earth and that action is necessary. ${ }^{36}$ This is occurring not only in developed countries but also in developing ones such as China, India, and Brazil. ${ }^{37}$ (This is not to overlook the deniers and opposers who make for formidable resistance (see below)).

In the sustainability revolution we see redevelopment of the electric car, emergence of hybrid cars, solar energy innovations and other renewable energy developments, "smart electric switches," recycling systems, banning or tighter regulation of chemicals, increased controls of many pollutants, movements to protect forests and threatened species. These changes take place more in some parts of the world than others, but there is a powerful and sustained thrust, involving tens of thousands of initiatives and innovations. The emerging social trend is manifested in the plans and actions of many international regimes,

\footnotetext{
${ }^{35}$ Obviously, there was growing and widespread concern with conservation, environmental pollution and degradation long before there emerged a "sustainability" concept, as suggested above.

${ }^{36}$ Some instances of radical steps have been accomplished such as the EU chemical directive REACH (2006) discussed earlier in which Swedish and other Scandinavian as well as Austrian EU agents and pressure groups played a significant role in passing it over the opposition of the European, American, and Japanese chemical industries as well as the political leadership of Germany, France, and the UK [20].

${ }^{37}$ Another way of thinking about this transformation is that a "green" or sustainalization world is emerging - just as an industrial world perspective emerged in and through the industrializing process. Tens of millions of people are considering, developing or adopting new conceptions, goals, techniques and technologies, and practices relating to a wide spectrum of environmental concerns and developments. The ongoing paradigm development - a gradual shift from the economistic, industrialization paradigm to one or more forms of a sustainability paradigm entail the establishment of new ways of thinking, acting, organizing, and regulating (in part, the establishment of a new global ethos and a cognitive-normative discursive framework). Sustainability ideas, norms, and values permeate an ever-increasing part of modern life and have a significant impact on everyday thinking and practices in substantial parts of the world.
}

international bureaucracies, national agencies, local and transnational activist groups and expert networks. At the same time, "earth system governance" can be understood as a political project that engages more and more actors who seek to change the current architecture of institutions and networks at local-, meso-, and globallevels in order to advance the cause of sustainability.

In sum, a revolution is taking place - not without conflict and struggle, and possibly not rapidly enough to save the planet (see below).$^{38}$ The "green revolution" represents multiple paradigm shifts, not only in production, technologies, consumables, and lifestyles, etc. but in governance, science and education, and practical ethics and related normative developments. The new paradigm (or family of paradigms) is spreading readily - horizontally - as manifested in new knowledge, values, and practices. "Green modernization" entails "green re-industrialization," "green capitalism," "green governance," "green thinking and lifestyles.", 99

Some of the drivers and facilitators of the sustainability revolution are: (1) the normative ethos and related collective pressures relating to environmental issues; (2) opportunities to make gains in fame and fortune; (3) opportunities for engaging with creative challenges; the excitement of innovating, experiencing the new, its opportunities as well as exhilarating uncertainties and risks; the paradigm shifts themselves entail new ways to frame, think, judge, and act that are challenges to be mastered and developed; (4) the availability of open, new sectors able to develop quickly on green

\footnotetext{
${ }^{38}$ The emerging sustainability paradigm is being established by a process of multiple initiatives facilitated by a diffusion of values, ideas, and practices through associations, communities, business, and political networks. There are not only values shifting - and some reordering (still limited) of priorities, but governance changes, and changes in many daily practices. The conditions of initiative and innovation encompass multiple agents who enjoy some power and means of structural control over their own situations and are able to make relatively autonomous independent decisions. This process results on an aggregate level in adaptations and shifts in the industrial paradigm complex and its particular institutional and cultural arrangements. The massive nexus of the latter is being challenged piece-by-piece by the sustainability paradigm. But the ongoing sustainability revolution is much more than a "Third Industrial Revolution" to which Jeremy Rifkin refers in his 2011 book [50]. But significantly Rifkin recognizes the organic character of the transformative processes.

${ }^{39}$ The transformation process is an organic one with many different agents in different sectors and at different levels driven by diverse motives and interests. Gradually, blueprints will emerge specifying standardized designs and strategies. Industrialization was also characterized first by such a highly organic phase and then later a more blueprint-like modality: where Germany, Japan, the Soviet Union, and others adopted and imposed particular industrialization designs.
} 
dimensions by utilizing new ideas, models, methods, technologies and techniques - in these sectors, there is often less resistance from established, resilient arrangements; (5) diffusion and imitation mechanisms through diverse social networks; (6) some strategic powerful sectors - such as energy and chemicals - are subject to particular attention and pressures to transform them, because energy forms such as fossil fuels are becoming increasingly scarce and also because they contribute significantly to pollution, GHGs, and climate change.

The pressures of the sustainability revolution are likely to continue and even to accelerate because of continuing environmental crises (that will not go away) and expanding outpouring of critical analyses and prognoses about the current damages, threats and hazards. While "sustainability" initiatives continue to grow and spread, the ongoing transformation will be no walkover. Rather, it is a development in the context of established social structures and power configurations (capitalist, socialist, Saudi Arabian and other Middle East oil producing monarchies) and powerful vested interests in what has been in many ways an historically successful industrialization/modernization paradigm. There is a formidable opposition (including deniers and opposers) among powerful interests, for instance, many in the established industrial-commercial-banking complexes and their allies. The struggle will be long and difficult. Particularly troublesome are efforts to deal with climate change, GHG emissions, the mammoth auto and related industries and the continuing use and sustained extraction (including new forms of risky extraction) of fossil fuels (the point of this paragraph relates to the discussion and illustrations in Part III).

Whether the sustainability revolution will be fast enough or comprehensive enough to save the earth-

\footnotetext{
${ }^{40}$ While the sustainability revolution shares the organic character of the industrial revolution, the two differ significantly in a number of ways, as would be expected given their obviously very different historical, institutional, and cultural contexts as well as the difference in levels of scientific and technical knowledge. (i) Complexity: sustainalization is taking place in a much more developed and complicated world in terms of institutions, cultures, and technologies including of course communications; for instance, the infrastructures of agriculture, manufacturing, government, science, education, etc. are very different; (ii) The numbers and diversity of stakeholders and regulatory and governance systems that must be taken into account is much greater (partly a result of democratization and partly global learning to deal with modern complexity); (iii) Our modern world has its established expectations about consumption levels, lifestyles and welfare (this is also the case in developing countries); (iv) There are greater explicit concerns about issues of general welfare, justice, human rights
}

planet remains to be seen. History provides numerous examples of great societies that collapsed, and visions that failed or were never realized. ${ }^{40}$.

In spite of the complexity and the many institutional and cultural as well as power constraints, sustainalization is likely to proceed much more rapidly than industrialization did in large part: (1) because of the vast resources and capabilities of modern science and technology; (2) because of the availability of more rapid and widespread advanced communications (scientific and technical associations, the WWW, twitter, Facebook, blogs linking people concerned about environment and sustainability and facilitating the spread of sustainability ideas and accelerating rates of innovation and application); (3) because of the large numbers of people and collective agents already mobilized and acting to drive sustainability innovations and transformations.

In sum, the transformation of entire societies (complex social systems made up of multiple institutions) entails processes in which society changes not only in many of its functions but more profoundly in terms of its structures, social relations, normative-cognitive frameworks, and institutional arrangements. ${ }^{41}$

To conclude, creativity is observable in individuals acting ostensibly on their own, and in networks, groups, organizations, and societies providing continuous access to key information, technical and aesthetic knowledge, critical judgments, materials, social support. In general, cultural, material, and agential infrastructures condition creative activities and developments.

\section{Discussion}

\subsection{Studies of innovation}

The previous section distinguished and illustrated social organizational contexts of creative activity. Each case was characterized by a social organizational form, with one or more innovators and entrepreneurs engaged in creativity processes. The agent(s) had a relatively high degree of relevant knowledge and capability in a given field $\mathrm{F}$ (or possibly, multiple, related fields),

\footnotetext{
${ }^{41}$ As Arthur [4:163] points out, entire fields and field complexes develop innovatively in a different way than do individual technologies (such as the mobile telephone or the jet engine). Field innovation is more a creative systemic development - not simply a new device or method but a new language for programming, new functionalities, and new global arrangements. Innovations take place in cascades, through multiple structures and elaborations of these (see cases above of societal transformations)
} 


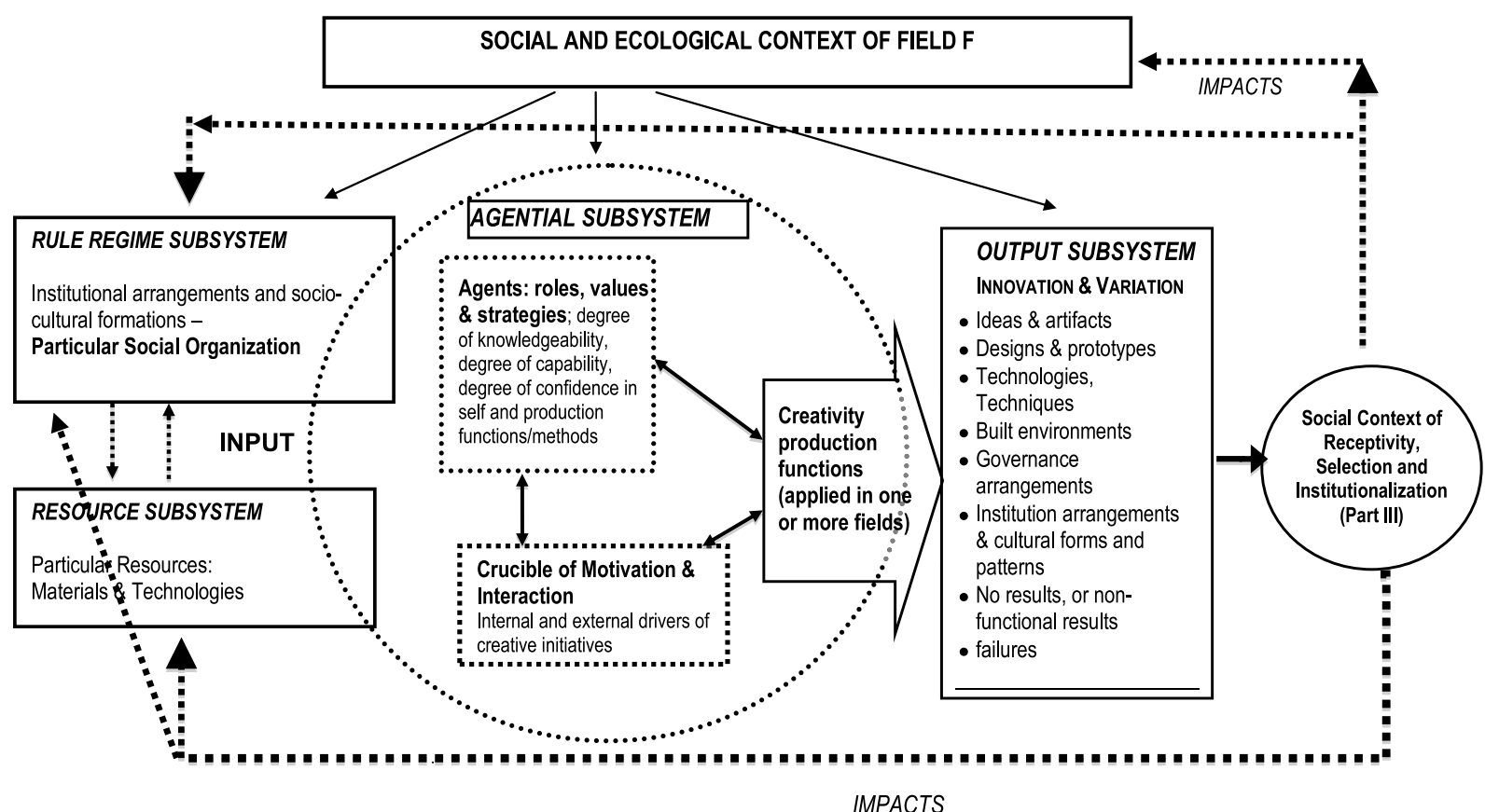

Fig. 3A. Model of Multiple Factors of Innovation and Creativity in a Social/Ecological Context (Legal, State Regulation, Markets, Socio-technical Systems and Infrastructures (see Fig. 1, Part I).

and believed in or possessed self-confidence in herself (themselves) and her/their methods/ modalities of creative action. They were motivated through their roles (for instance, possibly, in a professional or organizational context, or as a part of an informal group), situational incentives and pressures (failing systems or competitive challenges), and they utilized essential resources (materials and technologies) they possessed or had access to in the context F (see Fig. 3A and Table 1 below).

Selected cases are summed up in the following Table.

The social systemic approach to our investigations orients us to a few key factors that typically play a crucial role in generating innovation and creative development. For each case, we identified contextual conditions: whether an individual agent embedded in a cultural-institutional context, a network, organic group, administrated or constructed group, community or society arrangements in which innovation and creative developments take place, at varying rates and degrees of success. We emphasized agents' motivation, knowledge and capabilities, their levels of self-confidence and commitment, the types of resources (materials and technologies) they applied in the innovation process, and their strategies and creativity production modalities. With some probability they succeed in generating a desired innovative product or products. These creative outputs may be purely the result of "external" considerations produced for their impact on, or exchange with, the natural environment or with agents in the social environment of the producer; their productions may also be, at least in part, for the sake of improvement in their own social organization, the normative order, unique training of their members, adaptation of materials and technologies or, dealing effectively with unanticipated and unintended outcomes.

\subsection{Key selected patterns of innovative success or failure}

ASD theory identifies patterns of creative success and failure; high likelihood of success can be differentiated from low likelihood of success in producing a desired or appropriate innovations in a field $\mathrm{F}$ or fields. The differential patterns of creative success are a function of levels of resource availability, levels of knowledge and skills as well as degree of motivated self-confident agents, and their capability in performing creativity production functions.

Based on our general model and the empirical case studies and analyses in Part I and this part (II), we summarize below several theoretical and case study 


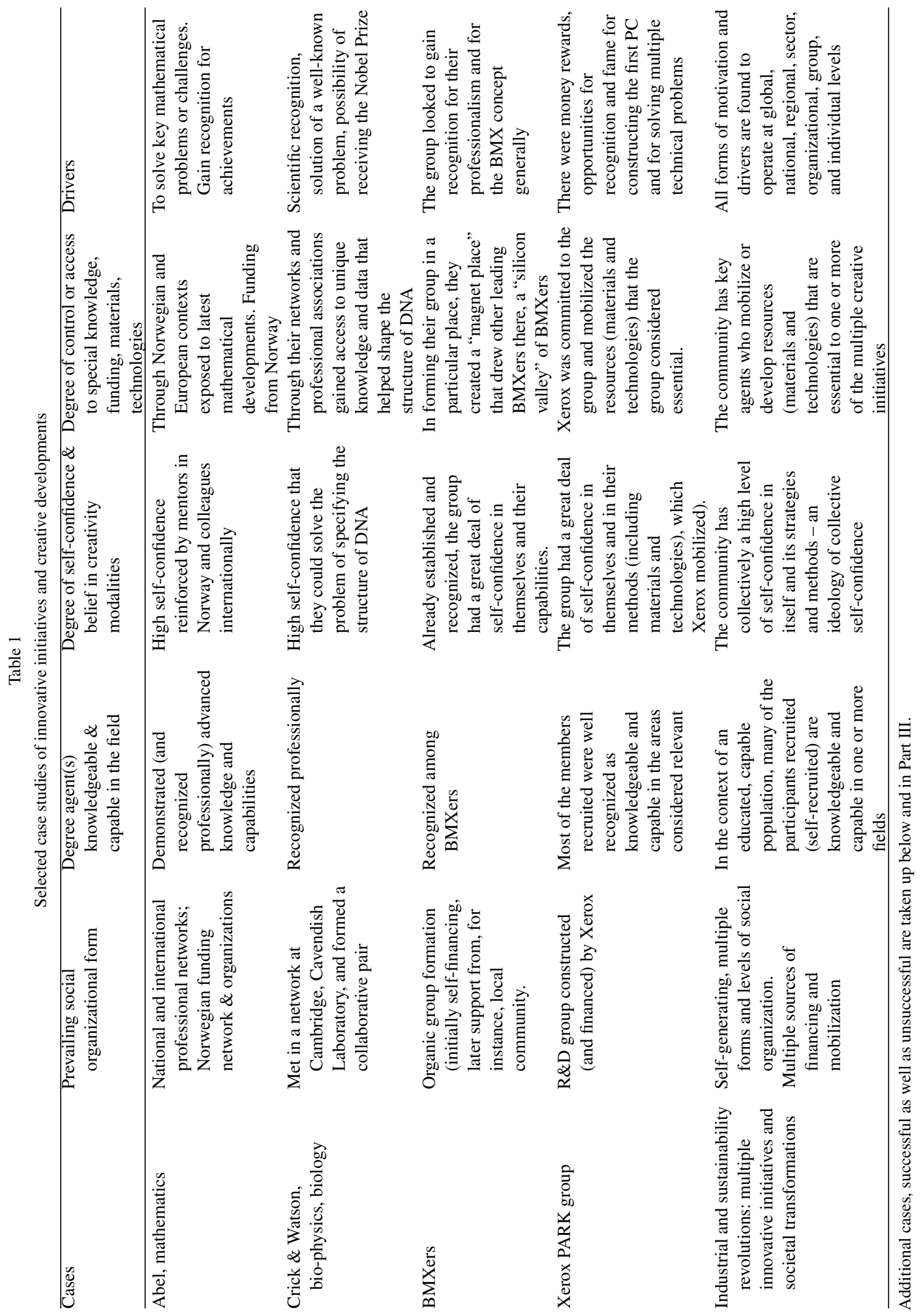


results in the form of selected principles (propositions) of likely innovation success and failure. The principles presented concern contextual factors and conditions, general systemic factors, rule regime and organizational factors, as well as agential factors.

\section{A. Contextual factors ${ }^{42}$}

We have emphasized the context(s) of creativity, in particular, the social organizational context (and more generally, the rule regime(s)), resources, and agential base(s) on which it is largely based.

Principle 1. The Multi-factor Contextuality of Innovation. A $n$ agent or agents launching innovative initiatives are shaped and influenced by multiple contexts (see Fig. 3A and 3B). Contexts are differentiated in terms of being with or without adequate networks of information and knowledge sources, resources (materials, technologies), people with or without relevant capabilities, motivation, and self-confidence able to participate in such initiatives as well as people in positions (economic or regulatory "authorities," "powerbrokers," "gatekeepers") able to facilitate the innovation initiatives as well as those having the power to reject or block the introduction of novelties (see Part III). ${ }^{43}$

Principle 2. Particularities of the Local Context F. The most immediate context is the field $\mathrm{F}$ where actors are engaged in innovative activities in a concrete situation involving particular types of resources (materials and technologies), particular types of knowledgeable agents (including inventors, entrepreneurs and technicians as well as power-brokers), particular types of social organization (and more generally rule regimes), and particular types of production processes and outputs. The local particularities are $F$-particularities, the special purpose technologies and processes as well as possibly the particular organizational arrangements and populations of knowledgeable, capable agents in the given field $\mathrm{F}$.

One can think of any given context as providing an infrastructure for potential creative activity. While much of our discussion has been focused on social organization/rule regimes, resources, and agents, we have systematically referred to normative regulation which may facilitate or constrain innovation and creative development. Thus, a global culture (with its

\footnotetext{
${ }^{42}$ Hughes [34, 36] and Staudenmaier [52] stressed the importance of contextual histories of innovation and technological development.

${ }^{43}$ Settings with innovative potentialities thus vary across space and the frequencies and distribution of innovative initiatives vary for different fields.
}

norms and values) of exploration, experimentation, and ultimately creativity helped drive the several industrial revolutions - in the 19th century in Britain and the USA and later Germany and France [49:26]. As Phelps [49] points out, "Even people with few and modest talents ... were given the experience of using their minds: to seize an opportunity, to solve a problem, and think of a new way or a new thing." Democratic culture played a role in the spread of such opportunities and developments (see footnote 2 and Principle 20).

\section{B. General systemic factors}

Principle 3. Multi-factor Pattern of Successful Innovative Initiatives and Creative Developments. ${ }^{44}$ An innovative initiative is likely to be successful under the following conditions: (a) there are sufficient quantities and qualities of inputs essential to the particular innovative initiative (including possible substitutes of sufficient quantities and qualities in case of deficencies); (b) the inputs have - or have been made to have compatible interfaces or correspondences making it possible to integrate them into functional entities with particular structural properties and performance patterns. (c) The goals (functions), designs and performance characteristics fit with (or at least

\footnotetext{
${ }^{44}$ In general, potentially creative community and societal contexts are characterized by surplus resources which can be mobilized for creative or innovative projects, a "leisure class" (not only aristocracy but a community of researchers and entrepreneurs with control over or access to resources (materials and technologies)), and powerful norms emphasizing creativity and discovery as well as competition for identity, fortune, and recognition. Even much more marginal communities than those discussed above often prove themselves able to mobilize and to initiate projects of considerable innovation and creative development. For instance, research on small island communities that are increasingly challenged by climate change and other environmental developments (rising sea levels, altered weather patterns, organic pollutants) show themselves to be highly innovative in not only technical/economic areas but in areas of governance and culture in their responses to these challenges [39]. In the area of energy, there are ongoing initiatives to establish and develop alternative energy technologies, for instance thermal energy in the Azores, wind and solar energy in the Canary Islands, among others. Also, building codes are being altered to facilitate the introduction of solar energy heating and to facilitate the construction or retrofit of energy efficient buildings. Innovations in governance are also commonplace. For example, the Organization of Eastern Caribbean States (OECS) was founded in 1981 to contribute to sustainable developments of its nine members, in particular in meeting their international legal obligations and responsibilities (e.g., about ozone depleting substances and biodiversity); it has also worked to harmonize their foreign policy and to promote economic integration (they created a currency union involving all OECS members except for the British Virgin Islands which prefers to use the US dollar).
} 
are not contradictory to) nature's laws and conditions at the same time that they are acceptable (consistent with) powerful social norms, institutional arrangements, and interests of powerful agents engaged in $\mathrm{F}$ and related contexts. The innovation is deemed initially "successful" if the constructed/entity (including new processes and institutional arrangements) is judged by the creator(s) to adequately perform the expected or designated function(s) and has appropriate properties (efficiency, reliability, etc.) at designated levels (see Part III).

Note: Multiple judgments are involved concerning "sufficient quantities and qualities", "qualified agents and experts," "compatibility," "correspondence," "appropriate policies," etc. Typically there is much uncertainty about these - except in cases where successes have already been realized, that is ex post (see Part III). (Under such conditions, the uncertainties have been in large part resolved). But, in general, there are multiple uncertainties to address and multiple problems to judge and resolve.

Principle 4. The Diversity of Creative Outputs: In our general framework, innovations and creative developments are generated in all areas of human affairs (see Part I, Table 1) with varying degrees of likelihood and effective functioning - in the diversity of contexts where initiatives are launched. This conception of innovation encompasses cases of self-construction where agent(s) innovate in creating or constructing new materials and technologies in a field F (and possibly more encompassing contexts): replacing some or many of the agents involved; or launching entirely new agents, new education and training in problem-solving and creativity; or, introducing a new social organization, a new type of network, group or organization; or new production processes including creativity modalities. Thus, there may be sequences if not cascades of innovations associated with creative initiatives [4] (see earlier discussions of industrial and sustainability revolutions).

Principle 5. Multiple Powers of Creativity. Creativity entails mobilizing and coordinating diverse powers and capabilities to produce an innovation: agential powers, structural and normative powers, resource "powers," and the powers of creativity modalities performed by capable, motivated agents [17]. ${ }^{45}$

\footnotetext{
${ }^{45}$ The innovation itself may entail a new capability or power providing value-added, changing material and/or social conditions, persons, social organization, other resources, etc.
}

Principle 6. Compatibility Factor. For any given creative initiative, when the components more or less fit together - with at least minimum necessary compatibility and coherence - the initiative is more likely to be successful. We envision a matrix of interlinked compatible requisites and correspondences in successful innovation. For instance, essential knowledge and capabilities of the agents involved would relate appropriately - in at least a rough way - to the materials and technologies utilized; the agents would fit knowledge-wise and performance-wise more or less with key rule systems, including the creativity modalities, that is, they would have the motivation, self-confidence, knowledge and skills to execute the appropriate creativity modalities in relation to the desired innovation. 46

The more incompatibilities among essential inputs into an innovative initiative in context $\mathrm{F}$, or between the goal and the inputs and outputs, the more likely the given initiative will fail with respect to its presumed goal or function. Because of environmental constraints (material, legal, regulative, technical), there may be multiple incompatibilities (critical restraining factors) to deal with before an innovation can be realized and made to function properly. And, conversely, the more the compatibility among ingredients and processes, the more likely that the innovative initiative will succeed, other things being equal. In general, the rule of minimum necessary compatibility and coherence applies; the components making up a promising innovation process must fit the goal(s) and one another to a greater or lesser extent.

\section{Agential factors}

Principle 7. Knowledgeable, Capable, and Selfconfident Agents. ${ }^{47}$ An agent (or agents) believing in themselves and in their methods and techniques) and embedded in rich knowledge and resource contexts in a field F (or complex of fields) are more likely to have - or

\footnotetext{
${ }^{46}$ Thus, if the innovation requires massive materials (Easter Island gigantic sculptures), one needs, for instance, having the means (the necessities of manpower, animal power, devices and technologies aiding movement) and the capability to organize and coordinate this, that is a certain level and quality of social organization is required. Or, in the case where lots of diverse knowledge needs to be mobilized and brought together and "coordinated", as in the Xerox PC or Manhattan projects, management must be capable of dealing with multiple gaps, tensions, and conflicts.

${ }^{47}$ The participating agent or agents are to a greater or lesser degree socialized in and carriers of knowledge, including institutional and cultural knowledge and able to draw, in general, on the resources in their established fields of interaction [17].
} 
be able to mobilize - the capacity to adapt create material culture and artifacts as well as rules, symbols, and cultural artefacts. Creativity is witnessed in the design and construction of new artifacts or entities, new ideas, symbols, theories, socio-technical systems, built environments, etc. Part of the knowledge relates of course to "problems-to-be-solved." 48

Principle 8. Multiple Creativity Modalities and Powers. Agents initiating an innovation process (or involved in an ongoing creativity process) conduct one or more creativity modalities: assembling, combining, adapting, experimenting, transforming, etc. (see Part I), which may or may not end in success depending on resource availability, the knowledge and capabilities of the agents, whether individual, group, or organization. Among other activities, aspiring innovator(s) engages in integrative operations - actions to eliminate or overcome incongruencies or lack of correspondences ("reverse saliences" or critical constraining factors in Hughes perspective $[34,35]$ ) that is, the innovator adapts or fits inputs to one another in relation to an emerging or constructed innovative entity; she fits agents/performers to the inputs and to the entity under construction. For instance, a human operator must properly interact or correspond with a machine or technical sub-system; the driver's setting in an automobile is made to correspond or fit with the dashboard and its visible monitoring; or, an automobile transmission sub-system is made to properly interface with the motor system.

In addition, she typically has to adapt the innovation to fit the context (hopefully without compromising its performance potentialities); she may also try to change the context to fit the innovation (but this typically calls for special powers over the environment). ${ }^{49}$

\footnotetext{
${ }^{48}$ Knowledge encompasses not only knowing what resources and agents are available in the field $\mathrm{F}$ but also knowledge about principles and methods, about how to work with available ingredients/components in creative activities, that is, about how to work, for instance, with relevant symbols, rules, algorithms, materials, imagined alternatives, new designs or productions, etc. Knowledge concerns also the relevant or context dependent rule systems, group configurations, socio-political and interactive potentialities and constraints, risks, and potential dead-ends. The components of the systems models have been presented earlier (see Fig. 2 in Part I and Fig. 3A in this part).

${ }^{49}$ Concerning correspondence or compatability, Hughes [34, 35] introduced the concept of "reverse salience" or critical restraining factors, which must be eliminated or overcome for the (technological) entity to function properly in a given context. Hughes [34:224] pointed out that the development of, for instance, leaded gasoline entailed not only "chemical integration" but institutional and organizational integration involving chemical companies, universities, automobile manufacturers, and petroleum refineries. A newly former
}

Principle 9. Cognitive Development and Learning. Those participating in an innovation initiative often acquire knowledge and skills over time, even as they may fail in early attempts. Hughes [34] stressed this in considering the development of American railroads and the Manhattan Project. The same pattern could be observed as the Wright brothers constructed the first airplane that flew successfully [42] and Edison and his "creativity factory" produced arguably the first effective incandescent bulb after two years of trying thousands of different materials and assessing the research of many others also trying.

Principle 10. Cognitive Diversity (based on social and intellectual mixes) is conductive to creativity. Diversity emerges in a natural way in urban type complexes, particularly trading and cosmopolitan cities. The mixing and movement of people makes for a spectrum of interacting perspectives and experiences and thereby contributes - as urban life has demonstrated over and over again - to creative developments. ${ }^{50}$

Principle 11: The Role of Marginal Agents and others who are inclined to think outside the box tend to play a key role in innovative initiatives, when they are allowed to, and are able to mobilize and gain access to essential resources and support to realize their innovative visions and designs. 51

enterprise, Ethyl Gasoline Corporation, formed by General Motors and Standard Oil of New Jersey, marketed the leaded gasoline. Or, another illustration is provided by the Manhattan Project which brought together and integrated science and engineering, industry (Dupont Corporation among others), and military - one among many projects to emerge as instantiations of the military-industrialacademic complex.

${ }^{50}$ Dissident individuals acting on their own - or coming together as a group - in a high status/knowledge rich/resource rich context is one of the processes whereby paradigmatic and institutional change occurs in academic or semi-academic (settings with high status or authoritative membership) obtain resources including students (more difficult for marginal academics and/or outsiders to recruit qualified people and robust resources). Some social organization designs build on the priciple of diversity in order to foster creativity [33]. That is, agent(s) with essential resources construct diversity through the exercise of meta-power and relational control in the intentional design and construction of social organization and normative regulation [18]. Along similar sociological lines, social movements by mobilizing people and resources generate reframing, rethinking, and reforming self, other, and the world around, that is revolutionary developments, as various socialist movements, the women's movement, varieties of Islamic and other religious movements have demonstrated in the past (see also the earlier discussions of the industrial and sustainability revolutions).

${ }^{51}$ People who are marginal, not fully socialized may have out of the box ideas and experiences. But in what ways does marginality relate to creative processes: Does it mean freedom from social 
Principle 12: Managing Diversity. While diversity is frequently conducive to innovation and creative development (Principles 10 and 11), it may also prove disruptive and disequilibrating, that is counterproductive in a potentially creative context.. Managing a diverse, creative group is, therefore, a major challenge: dealing with conflicts, misunderstandings, reluctance to collaborate - including even the sharing of data (this is discussed in Bennis and Bierdeman [8], particularly with respect to the Manhattan project but also in the case of PARC).

Principle 13. The Self-Confidence and Faith Factor. For purposes of an innovative initiative, it is essential for the innovating agent(s) to believe the innovation possible in a given time and place, and also to believe in one's self and the creativity methods/modalities she/they have at hand. In addition, the belief can be important in convincing others ("persuasive rhetoric") whose resources or support are necessary if the innovation is to be realized. (On the other hand, belief that an innovative initiative is not possible, or it will never succeed or will be rejected operates as a powerful constraint on creativity; see Part III).

Because self-confidence in one's knowledge and performance capabilities and in the methods/technologies and social organization are crucial factors in facilitating innovation, agents aspiring to be innovative try to maintain such confidence (even in the face of initial setbacks or failures), using a variety of means and strategies: for instance acquiring badges of competence and achievement; joining or belonging to - or forming an alliance with - high status, self-confident groups. There are also social psychological and interaction strategies and methods used often: Cognitive dissonance reduction strategies (reinterpreting or redefining cases of "failure"), use of particular confidence building discourses

and/or technical constraints. Or, does it mean intellectual ambiguity, as many of the Jews in Europe experienced it. Colm Toibin in the London Review of Books (January 5, 2012) refers to a Thorstein Veblen article on the prevalence of Jews in creative developments in Western culture. Jorge Luis Borges writes in a similar vein "because they act within that culture and at the same time do not feel bound to it by any special devotion" it is, therefore, easier for them to innovate. Similarly, for the Irish vis-á-vis the English. The Irish greats in literature and philosophy felt themselves to be Irish, to be different. This enabled them (for example Joyce, Beckett and also the non-English Pole Joseph Conrad) to make major innovations in English culture. Borges continues, "Similarly for Argentines and South Americans in general... we can take on all the European subjects, take them on without superstition and, with an irreverence that they can have, and already has had, fortunate consequences. See McLaughlin [45] concerning the concept of "optimal marginality." and rituals, and leadership rhetoric and persuasion in groups and organizations. 52

Principle 14: Principle of Multiple Motivations. As indicated in Part I, innovators and entrepreneurs may be motivated in diverse ways, curiosity, fun-seeking, competition, their particular roles and group membership which stress creativity, and, of course, the pursuit of wealth and fame. In general, there are multiple motivations and drivers including unconscious forces, attraction among participations (the mutual affection and even love between some pairs and team members [29]). ${ }^{53}$

\section{Rule regime, social organization and normative factors}

Principle 15. The Social Organizational Factors. Rule regimes and their realization in social organizational arrangements play a significant role in our descriptions and analyses of innovation and creative development

\footnotetext{
${ }^{52}$ Parker and Hackett [47] have noted that being in an environment that sheltered their group from early criticism is important for its selfconfidence in innovative initiatives . This is also what Corte [22] found in his study of professional athletes.

${ }^{53}$ There are multiple drivers of creative activities and developments - often combined in varying ways - as suggested by our concept of a "crucible of motivation" in Figs 2, Part I and 3A in this part and 3B in Part III. For instance, curiosity is a powerful driver - and in the modern world it is institutionalized in a variety of organizational forms: research labs, university departments, thinktanks, research and development units, among others. Also, various expected "gains" are well-known drivers - money, status, career, fame; satisfying expectations and demands of others such as employers, colleagues, or friends and family; the challenge of a problem-to-solve; necessity; play, curiosity, the euphoric experience of discovery or what Csikszentmihalyi $[23,24]$ refers to as "flow" or, in general, the emotional experience of constructing something, particularly something entirely new, or merely overcoming boredom (The creative experience of flow ([24]), euphoria, "eureka" which typically entails high levels of focusing, ignoring the "irrelevant" or uninteresting and mobilizing "capacities" and resources). Some persons cannot - or will not - accept the circumstances in a given field - its elements - and try to develop alternatives. In contrast, more compliant or more selfsatisfied persons - or those who feel they have much to lose by deviating from or violating established patterns - subordinate themselves to rules, authority, spiritual/symbolic culture, and, in general, the prevailing ethos (but nonetheless will do so in more or less creative ways). In addition to the modalities of learning and adaptation which all living being exhibit (as part of evolutionary sustainability), language, rules, procedures, rule regimes provide openness to creativity - multiple interpretations, applications and implementations which result in variation of performance (for instance, variation in "rule following"), the variety on which evolutionary selectivity operates. Concerning the multi-dimensionality of creative drivers, see [4, $6,18,38,51]$, and [55], among others.
} 
$[17,18,20]:{ }^{54}$ whether networks, organic or constructed groups, or transformational communities. As indicated earlier, rule regimes encompassing roles, norms, production functions (in particular, creativity modalities), cultural formations, and institutional arrangements impose potential constraints on action and cognitive possibilities but also generate opportunities for actors to behave in ways that would otherwise be impossible, for instance, to coordinate with others, to mobilize and to gain systematic access to strategic resources, to command and allocate substantial human and physical resources, and to solve complex social problems by organizing collective exchange, deliberation, and decision-making.

Principle 16. Organic Formation of a Collaborative Circle (self-formation and sustainability) without powerful patrons and/or mentors (intellectual/academic, economic, political/administrative) in the field $\mathrm{F}$ where the collaborative circle of members forms to develop/sustain creative work. The members generate in their group relations "self-confidence", emotional support, exchange and dialectics of ideas - in order to challenge established cognitive/intellectual orthodoxies (for example, a mainstream paradigm) and create a new vision and paradigmatic framework. The group develops identity, group structure, concepts and methods ("practices") that distinguish the group from other groups [14].

Principle 17: Administratively Organizing for Creativity [21, 33]. In the case of innovative groups engineered or legislated by an employer or authority, group members (individuals or collectives) may be expected to innovate by their employer or the group or organization in which they participate. Incentives are provided, norms and sanctions are applied.

\footnotetext{
${ }^{54}$ In addition to coordinating, organizing and regulating social action and creativity modalities, rule regimes play an important role in cognitive processes and developments (See Principles 9 and 10), in part by providing interpretative schemes as well as enabling actors to organize and to frame perceptions and interpretive schemes in a given institutional setting and contributes to making social life more rather than less orderly and predictable. Finally, social rules also play a key role in normative and moral judgments and communications about innovative initiatives and creative development. Participants refer to the rules in giving accounts, in justifying or criticizing what is being done (or not done), in arguing for what should or should not be done, and also in their social attribution of who should or should not be blamed for performance failures, or credited with success. Actors also exploit rules when they give accounts in order to try to justify certain actions or failures to act, as part of a strategy to gain legitimacy, or to convince others that particular actions are "right and proper" in the context.
}

Already in 1876 Edison established the first industrial lab in Menlo Park to produce constant technological innovations with skilled workers coming from many part of the world. Edison's "invention factory" was or became a prototype that spread in the US and Europe. In the USA by 1929 there were more than 1000 industrial labs designed to continually produce innovations, often in multiple areas. This organizational principle is obvious now to most who aim for systematic innovation in science, $\mathrm{R} \& \mathrm{D}$, engineering, business, and politics (e.g. policy thinktanks, etc.) $[8,34]$.

Principle 18. Normative Order: In addition to the key arrangements of social organization, a normative order, as a part of a rule regime, is central in encouraging (or possibly discouraging) creative initiatives and developments, for instance, norms encouraging selfconfidence, initiative, tolerance, and collaboration. On the other hand, some norms and situational conditions may support conformity and opposition to novelty and to creative initiatives and developments.

Principle 19. The Significance of Democratic culture. The association of democratic culture with innovativeness and creative development has been long recognized [49]. It facilitates and encourages innovation and creative development through norms of equality, mutuality, and tolerance of deviance and difference in general. At the same time, it also contributes to a dynamic, changing society and increased unpredictability (see Principle 20 and footnote 2).

Principle 20. Unintended and Unanticipated Consequences of Innovativeness. Innovations typically generate unintended and unanticipated consequences. Thus, while certain problems may be solved through innovative initiatives, new challenges and problems emerge. A "vicious circle" is generated: Creative development $\rightarrow$ new problems $\rightarrow$ problem-solving efforts $\rightarrow$ creative development $\rightarrow$ further problems, etc.

Our theory identifies, in general, likelihood patterns of success in producing desired or appropriate innovations in a field or fields as a function of levels of resource availability, levels of agent knowledgability, motivation and self-confidence and the capability of performing creativity modalities. Unless the innovation is simply a minor adaptation of an existing functioning entity, the initiative will entail multiple uncertainties. In general, some of the uncertainties can be reduced through trial and error, experimentation, learning by doing, finding out from others what does or does not work. 


\section{Concluding remarks}

In our general framework, innovations and creative developments are produced in all areas of human affairs (see Part 1, Table 1), although likelihoods are uneven as are the degrees of originality.

An appropriate or "advantageous" context is characterized by the key ingredients for generating innovation and creative developments: motivated, capable, self-confident agents and entrepreneurs; resources (materials and technologies); effective social organizational arrangements and appropriate normative regulation, the setting in which the "ingredients" of people, resources, and rule regimes are brought together (or emerge organically) and are mixed so as to produce innovations (novelties diverging from existing entities, processes, or conditions).

The likelihood of successful innovation increases to the extent that the goals, designs, inputs, and intended functioning of the innovation fit with one another and with nature's laws and at the same time are consistent with influential social norms, institutional arrangements, and the interests of powerful agents in the context.

It follows from our multi-factor model that creativity initiatives may fail for any of a number of reasons: Poor quality of key ingredients (including in the case of groups, their members), or lack of ingredients altogether, or incompatibilities among them or in relation to goals; or incompatibility of innovative designs with nature's laws or with influential social norms, institutional arrangements, and the interests of powerful agents makes for unlikely success in innovation efforts.

\section{Acknowledgments}

We are grateful to earlier collaboration with Tom Baumgartner, Marcus Carson, Philippe DeVille, Jerry Ellig, Peter Hall, Ilan Kelman, and Alison Woodward who have played a significant role in the development of the sociology of creativity presented in this part.

\section{References}

[1] E. Ahren, Death, Modernization and the Body: Sweden 18701940. Rochester: Univ. of Rochester Press, 2009.

[2] S. Andersen and T.R. Burns, Societal Decision-making: Democratic Challenges to State Technocracy. Aldershot, Hampshire, U.K.: Dartmouth Publications, 1992.

[3] M.S. Archer, Realist Social Theory: The Morphogenetic Approach. Cambridge: Cambridge University Press, 1995.
[4] W.B. Arthur, The Nature of Technology. New York: Free Press, 2009.

[5] J. Ayers, The Sustainability Revolution http://www.vanderbilt. edu/Sustainability/book/S1C1_handout.pdf 2011.

[6] T. Baumgartner and T.R. Burns, Transitions to Alternative Energy Systems: Entrepreneurs, Strategies, and Social Change. Colorado: Westview Press, 1984.

[7] H.S. Becker, Art Worlds. Berkerly: University of California Press, 1982.

[8] W.G. Bennis and P.W. Biederman, Organizing Genius: The Secrets of Creative Collaboration. Basic Books, 1997.

[9] W. Buckley, Sociology and Modern Systems Theory. Oxford, England: Prentice-Hall, 1967.

[10] T.R. Burns, "The Sustainability Revolution: A Societal Paradigm Shift. Sustainability.” Vol. 4:1118-1134, 2012.

[11] T.R. Burns, "Sustainable Development." In: ISA Sociopedia. London: Sage Publications, 2013.

[12] T. Burns, "System Theories" In: The Encyclopedia of Sociology, Blackwell Publishing, Malden, Mass, 2006.

[13] T.R. Burns, T. Baumgartner and P. DeVille, Man, Decisions, and Society. London: Gordon and Breach, 1985.

[14] T.R. Burns, U. Corte and N. Machado, "Toward a Universal Theory of the Human Group: Sociological Systems Framework Applied to the Comparative Analysis of Groups and Organizations." ULI/CIES Report No. 191/2014. Lisbon: University of Lisbon Institute/CIES, 2014.

[15] T.R. Burns and T Dietz, "Revolution: An Evolutionary Perspective.” International Sociology 16(4)(2001), 531-555.

[16] T.R. Burns and T. Dietz, "Cultural Evolution: Social Rule Systems, Selection, and Human Agency." International Sociology, Vol. 7:259-283, 1992.

[17] T.R. Burns and H. Flam, The Shaping of Social Organization: Social Rule System Theory with Applications. London: Sage, 1987.

[18] T.R. Burns and P. Hall (eds.), The Meta-Power Paradigm Impacts and Transformations of Agents, Institutions, and Social Systems Capitalism, State, and Democracy in a Global Context. Peter-Lang publishing, 2012.

[19] R. Carson, The Silent Spring. Houghton Mifflin: Boston, Mass, 1962.

[20] M. Carson and T.R. Burns and Dolores Gomez Calvo. 2009 Public Policy Paradigms: Theory and Practice of Paradigm Shifts in the European Union. Peter Lang, Frankfurt/New York/Oxford, 2009.

[21] K.K. Chen, "Organizing Creativity: Enabling Creative Output, Process, and Organizing Practices." Sociology Compass 6(8)(2012), 624-643.

[22] U. Corte, "A Refinement of Collaborative Circles Theory: Resource Mobilization and Innovation in an Emerging Sport." Social Psychology Quarterly 76(1)(2013), 25-51.

[23] M. Csikszentmihalyi, "Society, Culture, and Person: Creativity." In: R. J. Sternberg (ed.). Cambridge: Cambridge University Press, 1990.

[24] M. Csikszentmihalyi, Creativity: Flow and the Psychology of Discovery and Invention. New York: Harper Perennial, 1996.

[25] R. Collins, The Sociology of Philosophies: A Global Theory of Intellectual Change. Belknap Press of Harvard University Press, 1998. 
[26] R. Collins, "Collaborative Circles: Friendship Dynamics and Creative Work (review)." Social Forces 83(1)(2004), 433-436.

[27] E. Durkheim, The Elementary Forms of Religious Life. Free Press, 1965.

[28] A.R. Edwards, The Sustainability Revolution: Portrait of a Paradigm Shift. Gabriola Island, Canada: New Society Publishers, 2005.

[29] M.P. Farrell, Collaborative Circles: Friendship Dynamics and Creative Work. University of Chicago Press, 2001.

[30] M. Granovetter, "Economic Action and Social Structure: The Problem of Embeddedness", American Journal of Sociology, 91(1985), 481-510.

[31] A.B. Hargadon and B.A. Bechky, 'When Collections of Creatives Become Creative Collectives: A Field Study of Problem Solving at Work.' Organization Science 17(4)(2006), 484-500.

[32] A.B. Hargadon and R.I. Sutton, 'Technology Brokering and Innovation in a Product Development Firm.' Administrative Science Quarterly 42(4)(1997), 716-49.

[33] R. Hollingsworth, E.J. Hollingsworth and D.M. Gear, (Eds.). Major Discoveries, Creativity and Dynamics of Science, edition echoraum, Vienna, 2011.

[34] T. Hughes, American Genesis: A Century of Invention and Technological Enthusiasm 1870-1970. New York: Viking, 1989.

[35] T. Hughes, Networks of Power: Electrification in Western Society, 1880-1930. Baltimore, MD: The Johns Hopkins University Press, 1983.

[36] T. Hughes, The Development of Western Technology Since 1500. New York: Macmillan, 1964.

[37] V. John-Steiner, Creative Collaboration. Oxford University Press, USA, 2000.

[38] J. Kaufmann and R.J. Sternberg, (Eds.). The Cambridge Handbook of Creativity (pp. 145-173). New York: Cambridge University Press, 2010

[39] I. Kelman, T.R. Burns and N. Machado, "Islander Innovation: A Research and Action Agenda on Local Responses to Global Issues." Island Cultures. Vol. 4:34-41, 2015.

[40] P.H. Lepenies, An inquiry into the roots of the modern concept of development. Contribution to the History of Concepts 4(2008), 202-225.

[41] N. Machado, "Governance of End of Life: The Case of Sweden.” In: Bengt Larsson, Martin Letell and Hakan Thorn (eds.) Transformation of the Sweden Welfare State: From Social Engineering to Governance? London: Palgrave Macmillan.
[42] D. McCullough, The Wright Brothers. New York: Simon \& Schuster, 2015.

[43] J.L. Martin, "What is Field Theory." American Journal of Sociology. Vol.109(\#1)(2003), 1-49.

[44] J. Nikoloyuk, T.R. Burns and R. de Man, "The Promise and Limitations of Partnered Governance: The Case of Sustainable Palm Oil. Corporate Governance, Vol. 10(2010), 59-72.

[45] N. McLaughlin, "Optimal Marginality: Innovation and Orthodoxy in Fromm's Revision of Psychoanalysis." Sociological Quarterly 42(2)(2001):271-288.

[46] N. McLaughlin, "Collaborative Circles and Their Discontents." Sociologica, No.2(2008), 1-35.

[47] J.N. Parker, Hackett and E.J. Edward, "Hot Spots and Hot Moments in Scientific Collaborations and Social Movements." American Sociological Review 77(1)(2012), 21.

[48] J.F. Padgett and W.W. Powell, The Emergence of Organizations and Markets. Princeton University Press: Princeton, NJ, 2012.

[49] E. Phelps, Mass Flourishing: How Grassroots Innovation Created Jobs, Challenges, and Change. Princeton, N.J.: Princeton University Press, 2013.

[50] J. Rifkin, The Third Industrial Revolution: How Lateral Power Is Transforming Energy, the Economy, and the World. New York: Palgrave, 2011.

[51] R.K. Sawyer, Explaining Creativity: The Science of Human Innovation. Oxford University Press, 2012.

[52] J. Staudenmaier, Technology's Storytellers. Cambridge: MIT Press, 1985.

[53] P. Trompette, "Political Exchanges in the French Funeral Market." Management \& Organizational History 6(1)(2011), $13-35$.

[54] P. Trompette and M. Lemonnier, "The Standardization of the Supply Chain from Death to Disposal: Inter-professional Coordination in the Area of Care of the Dead." ESP Exploratory Workshop on "From Standards to Concerted Programs of Collective Action," Paris, France, 5-8 December, 2007.

[55] A.E. Woodward, J. Ellig and T.R. Burns, Municipal Entrepreneurship and Energy Policy: A Five Nation Study of Politics, Innovation, and Social Change. New York: Gordon and Breach, 1994.

[56] M. Zeleny and K.W. Hufford, "The Application of Autopoiesis in Systems Analysis: Are Autopoietic Systems Also Social Systems?" Int J General Systems 21(2)(1992), 145-160.

[57] M. Zeleny, "Autopoiesis (Self-production) in SME Networks," Human Systems Management, 20(3), 201-207. 